\title{
FINANCIAL CONSTRAINTS VERSUS FINANCIAL FLEXIBILITY: WHAT DRIVES ZERO-DEBT PUZZLE IN EMERGING MARKETS?
}

\author{
D. V. ILIASOV, M. S. KOKOREVA \\ National Research University Higher School of Economics, Moscow, Russia
}

\begin{abstract}
This study is focused on gaps in the theory of capital structure research regarding the phenomenon of zero-debt behavior. On the sample of firms from 21 countries with emerging capital markets over the period of 2010-2015, we show that the zero-debt policy choice is firstly driven by financial flexibility motive, while financial constraints could be regarded as the second motive. We show that major determinants of the zero-leverage choice are growth opportunities, profitability, business risk and cash holdings. We find that all these firms are smaller, less profitable, riskier and possess high cash holdings. Moreover, we find that macroeconomic conditions have lower influence on the debt policy decision in comparison with corporate determinants.
\end{abstract}

Keywords: financial constraints, financial flexibility, zero-debt, capital structure.

JEL: G32.

One of the puzzles in capital structure (CS) theory that have not been fully explained yet, is the presence of firms following the low leverage or even zero leverage policy. The proportion of zero-debt (ZD) firms varies from country to country but the motives that make these firms to follow low debt or
ZD policy are not clear and lack theoretical basis at the moment.

The classic theories of capital structure could not explain the puzzle. The static tradeoff theory [Kraus, Litzenberger, 1973] states that firms tend to reach the optimal capital structure through balancing between mar-

This paper is an output of a research project implemented within NRU HSE's Annual Thematic Plan for Basic and Applied Research. Any opinions or claims contained in this paper do not necessarily reflect the views of HSE.

Postal Address: 20 Myasnitskaya ul., National Research University Higher School of Economics, Moscow, 101000, Russian Federation.

(C) D. V. Iliasov, M.S. Kokoreva, 2018

https://doi.org/10.21638/spbu18.2018.305 
ginal benefits (cheaper financing, tax-deductible interest expenses) and marginal costs (costs of financial distress) from the use of the additional unit of debt. But this theory could explain the decision of the company only in one period as it is not dynamic. In the case of unlevered companies, the theory would state that their bankruptcy costs are too high with the respect to tax gains, but previous research show that this is highly unlikely for zero-debt firms [Korteweg, 2010]. Dynamic trade-off theory version [Fischer, Heinkel, Zechner, 1989] that supposes the constant adjustment of the actual capital structure to the time-varying target level also fails to explain the existence of zero-debt companies.

An alternative model for capital structure, the pecking order theory [Myers, Majluf, 1984], explains the choice of financing with the following hierarchy of sources. Firstly, companies prefer to rely on their retained earnings reducing the costs of information asymmetry through not relying on external funds, then they could use the debt capital, while the equity issue is the most expensive source of financing that is applied as a last resort. This order could be explained by the different degree of costs related to each source with the information asymmetry. However, in several emerging countries (China, Czech Republic, Slovakia, Russia) the empirical tests of this theory have shown the reverse order [Chen, 2004; Delcoure, 2007]. That fact led to the appearance of the modified pecking order theory, stating that financing through equity is more preferable than that of debt. Neither of theories specifications could explain however the stable zero-debt policy.

Even if the trade-off or the pecking order theories could explain the zero leverage in one definite period, they are not able to explain the tendency of increasing zerodebt firms nor they could be used to predict the financing choice of the firms in the future.
Estimation of ZD behavior can be useful and necessary from an empirical perspective, because the factors that lead firms to follow ZD policy are more likely to be dominating for these firms [Strebulaev, Yang, 2013]. Moreover, we should consider that ZD level may not be voluntary chosen. The mysterious fact in this pattern comes from the motives which force firms to follow no-debt policy, particularly the peculiarities of financial constraints and a mode deliberate choice of financial flexibility issues. Thus, we add to the literature on zero-debt puzzle by proposing the analysis of two motives (financial constraint and financial flexibility), that could possibly explain the increasing role of ZD phenomenon.

Secondly, the current literature on ZD choice is mostly focused on developed markets.

In this research, we focus on the ZD phenomenon of firms' CS from the emerging markets, making a focus on the motives which cause these firms to adopt ZD policy. Even though there have been several attempts to analyze the ZD puzzle in separate emerging countries, our research tends to explain the ZD policy choice from different perspectives: the impact of firms' financial constraints and financial flexibility motives, the influence of firm- and country-specific characteristics on the choice of ZD policy. Such complex and deep analysis hasn't been made for the emerging capital markets yet.

We aim to provide the new insights into the zero-debt phenomenon by analyzing firms' behavior, incentives and drivers for choosing the ZD policy. We evaluate the sample on the basis of financial flexibility and financial constraints motives to make comprehensive comparison of motives of the ZD choice among firms from emerging markets.

Our research demonstrates the results of capital structure choice among the large and small public companies with zero-debt (ZD), zero long-term debt (LTZD), almost zero-debt (AZD) levels from countries with emerging

RMJ 16 (3): 407-434 (2018) 
markets (Asia, South and Central America, East Europe, Africa). We find out that search for financial flexibility tend to be the major motive to have zero-leverage which is followed by financial constraints motive. We show that the major determinants that explain the choice of zero debt policy are those connected with the unpredicted future results of the firm. We prove moreover that macroeconomic conditions matter less for the zero-debt puzzle as compared with the corporate ones.

The rest of our study is structured as follows: we provide the literature overview, our next section describes the methodology of the analysis, the next one shows the sample construction and data description, then the section that covers the results of the econometric analysis and robustness tests follows, and the conclusions of our study are highlighted in the last section.

\section{Literature review}

\section{The zero-debt phenomenon in related literature}

The notion that debt conservatism of firms on average is mainly inherited by ZD firms has not gone unnoticed in financial research [Korteweg, 2010]. According to the recent studies, inability to use or increase debt level is inherited by firms at the introductory phase of the life-cycle, which can face volatile earnings and lower tangibility [Dang, 2011; Strebulaev, Yang, 2013; Bessler et al., 2013]. The ZD policy patterns are observed internationally and exist in around 20 countries [Bessler et al., 2013].

The literature on ZD follows two tracks. First, there have been several attempts to define the determinants of CS choice among the firms without debt in their balance sheet by separating these determinants into firmand country-level characteristics [Bessler et al., 2013]. The second track analyzes the motives which cause firms to follow ZD in their CS.
Country-level characteristics. The possible explanation of the ZD phenomenon can be related to the country-specific factors which force firms to use debt conservative policy. Firms are more likely to have high debt ratios among countries with more stable and healthier economic conditions [Djankov, McLiesh, Shleifer, 2007]. A negative relationship between the likelihood of a firm to be classified as ZD and the relative size of the deposits in a country [Bessler et al., 2013] was found, which indicates that financial intermediation encourages the use of corporate debt [Booth et al., 2001].

Despite the fact that the ZD puzzle exists at the major financial markets there are differences among countries due to the level of their capital market development, creditors protection and legal system. Countries with high creditors protection and a common law show the higher fraction of ZD firms [Bessler et al., 2013]. The common law system offers better protection for external investor than the civil law one, and as a result there is a better access to external financing and higher security values [La Porta et al., 1998; La Porta et al., 2002].

The key characteristics of emerging markets are high investment opportunities and their respective risks, low stock markets liquidity, lack of information transparency, the importance of insider information and the lack of proof of the market efficiency hypothesis, as well as small volumes of trading in financial markets. These markets are also characterized by multilevel ownership structure leading to urgency of agency conflicts and, accordingly, the necessity of testing the significance of agency capital structure motives in these markets [Bekaert, Harvey, 2003]. The authors also note another no less important characteristic: the weak development of corporate governance, which, among other things, leads to high costs for equity. Therefore, we suppose that country level determinants could influence firms' decisions to keep unlevered structure 
in emerging capital markets. Firm-level characteristics. Previous research show that ZD firms tend to be smaller, keep higher cash reserves, show higher market-to-book ratios and higher payout ratios [Dang, 2011; Devos et al., 2012; Strebulaev, Yang, 2013].

The ZD behavior can be related to business risk. Taking into account that costs of financial distress are a positive function of asset volatility, the presence of ZD pattern is likely to be increasing with higher business risk [Bessler et al., 2013]. This statement holds for firms possessing illiquid tangible assets which cannot be reallocated in the time of bad macroeconomic events [Campello, Giambona, 2013]. Decreasing or entirely de-levering the amount of debt in CS, a firm reduces shareholders' total risk exposure [Meulbroek, 2002].

The link between CS and payout policies makes the understanding of the debt conservatism puzzle more complex. The ZD firms are not homogeneous but consist of two distinct groups with different levels of financial constraints, namely dividend payers and nonpayers [Dang, 2011]. Either debt or dividends can be effective tool to reduce the agency problems regarding free cash flow [Easterbrook, 1984; La Porta et al., 2000; Fama, French, 2002]. Good equity market traits ZD firms accompanied by high dividend payouts [Byoun, $\mathrm{Xu}, 2013]$. There are several agency models which assume that firms with high profitability direct larger fraction of their earnings to debt re-payments or dividend payouts to prevent managers from wasting free cash flow [Jensen, Meckling, 1976; Jensen, 1986; Easterbrook, 1984]. As the dividend and debt policies help in solving free cash flow problems, firms obtaining large profits may show high payout ratio instead of using debt [DeAngelo, DeAngelo, 2007]. Therefore, highly profitable and mature firms may solve the agency problem caused by free cash flow, showing large dividend payouts instead of debt usage, and consequently become debt-free.
The motives for zero-debt choice

Having defined the potential influential characteristics, we still should analyze the motives which cause firms to restrain debt in their CS.

Current literature on ZD puzzle investigated the following set of possible motives: financial constraints [Benmelech, Bergman, 2009], financial flexibility [Marchica, Mura, 2010; Muradoğlu, Sivaprasad, 2012; De Jong, Verbeek, Verwijmeren, 2012; ArslanAyaydin, Florackis, Ozkan, 2014], managerial entrenchment [Jensen, Meckling, 1976] or as a reaction to macroeconomic changes [Antoniou, Guney, Paudyal, 2008; Cook, Tang, 2010]. As soon as the forced motive (financial constraints) and the deliberate one (financial flexibility) are the motives tend to play the major role according to the literature on developed markets, we investigate whether this is true for emerging markets as well controlling for macroecomic conditions. Thus, this paper contributes to the literature by checking the validity of these motives on emerging capital markets.

There are various suggestions about the characteristics of financially constrained firms. The presence of asymmetric information related to asset risk leads to increased costs of debt issuance, and as a result firms are rationed by lenders [Stiglitz, Weiss, 1981]. Also, the new borrowers without a good reputation may face difficulties in getting debt financing [Diamond, 1991]. The ZD firms with limited choices are constrained in their debt capacity and unable to enter debt markets, but not all of them suffer from supply-side constraints, and thus ZD firms may be classified as either financially constrained or unconstrained [Bessler et al., 2013]. Without having sufficient debt capacity, the constrained firms have to follow the ZD policy. The use of external equity is more pronounced among small firms, high growth firms, and low profit firms [Fama, French, 2005; Gatchev, Spindt, Tarhan, 2009]. Concerns about future financing abilities as 
well as underinvestment situations are main determinants for constrained firms regarding cash holdings [Almeida, Campello, Weisbach, 2011].

The financial flexibility is the ability of an institution to make effective measures for trends changes of cash flow as a response on the unexpected needs and opportunities [King'wara, 2015]. The decision to issue debt is desirable, whilst the borrowings opportunity costs suggest that the target CS is more conservative than predicted by the trade-off model, and firms which stay financially flexible keep large cash holdings [DeAngelo, DeAngelo, Whited, 2011]. Also, these firms are able to reduce investment distortions due to their better access to debt markets during crisis times. These firms are aiming to save debt capacity for more constrained future periods [De Jong, Verbeek, Verwijmeren, 2012].

\section{Implications of current literature to the zero-debt puzzle among the emerging markets}

The CS puzzle presence among firms in Central-Eastern Europe provides some facts and questions, which cannot be explained using traditional approaches. There is a relatively low debt level among East European firms [Jõeveer, 2006]. The research uses the country- and firm-specific factors as the main determinants of leverage change for firms with different size - small or large ones. The low level of debt financing in Hungary and Poland relates to supplyside effect [Cornelli, Portes, Schaffer, 1996; Hussain, Nivorozhkin, 1997]. The financial constraints among Hungarian firms are the result of the combination of the financial incentives of firms and credit rationing within the financial environment [Nivorozhkin, 2007]. These constraints can impede the access of firms to long-term financing as well as their ability to grow [Klapper, Sarria-Allende, Sulla, 2002].The debt ratio of firms which belong to the transition countries remains lower than in the
EU countries [Nivorozhkin, 2005]. The development of credit markets and economic environment stabilization in the emerging countries can explain the variation of firm's debt ratio.

Literature on zero-debt puzzle in emerging markets has only started to appear.

From the comparison of firms in developed and emerging markets it was found out that the culture and attitude to debt matter for the zero-debt decisions [Ghoul et al., 2018]. As the sample included the data of 1990-2010 it lacks the period of the major zero-debt firms rate increase, which could be provoked by different motives. The research on Indian market [Deb, Banerjee, 2015] provide a focus on the performance of zero-debt and levered firms showing that the formers' results are greater for the studied period of 2000-2007.

Considering the lack of research on the motives of ZD puzzle in the emerging capital market, we focus our research on the issue to provide a contribution to the literature on capital structure formation.

\section{Methodology}

We start the analysis from defining two motives measures: the financial constraints measure and the financial flexibility measure. According to the previous section, being the financially constrained or unconstrained, and financially flexible or inflexible, the firms' motives to adopt ZD policy should differ. Our hypotheses could be divided into two groups: first group estimates the determinants of probability to be debtfree, the second one tests the characteristics inherited by the ZD firms.

The determination of financial constraints and financial flexibility measures

Financial constraints. Existing literature aims to evaluate financial constraints from firms' statements relating to their funding situation or changes in investment plans, their actions (dividends paying or not), or 
their characteristics (age or size, having low leverage or without credit rating) [FarreMensa, Ljungqvist, 2016].

The one of the most popular financial constraints measure according to the frequency of usage in studies is the $\mathrm{KZ}$ index [FarreMensa, Ljungqvist, 2016]. This index has been developed by [Kaplan, Zingales, 1997] using a text-based approach. The actual KZ index uses five readily financial variables: cash flow, market-to-book, leverage, dividends, and cash holdings [Lamont, Polk, SaáRequejo, 2001]. The index loads positively on market-to-book and leverage and negatively on cash flow, dividends, and cash. There is implicit assumption that the financial constraints don't vary over time not over the business cycle.

In [Hadlock, Pierce, 2010] authors have updated [Kaplan, Zingales, 1997] text-based approach and have created their own index of financial constraints (SA index). We use the SA index because it is based on the size and age of the firm, the influential firm characteristics, which are less dependent on the accounting standard and are more transparent on emerging markets as compared to the elements of KZ index. Moreover, this measure helps us to enlarge the sample, since size and age information is available for greater number of companies. ${ }^{1}$ This index proposes negative loads for size and age, and positive one for size-squared:

$$
\begin{aligned}
S A & =0.737 \cdot \text { Size }+0.043 \cdot \text { Size }^{2}- \\
& -0.040 \cdot \text { Age },
\end{aligned}
$$

${ }^{1} \mathrm{SA}$ index uses the text-based analysis to determine the respective coefficients. This index is widely used for determining the firms' financial constraints issues by both academics and market practitioners in developed and emerging economies, though the coefficients haven't been recalculated. Due to the lack of evidence of SA index recalculation, we have adopted the approach that has proved its reliability for our analysis. Considering the potential bias of such approach, recalculation of SA index based on text analysis of sampled firms seemed highly difficult to conduct and was of the scope of our research. where Size is the logarithm of the total assets, Age is the number of years the firm is listed or the number of years after the IPO took place.

As with the $\mathrm{KZ}$ index, subsequent users of the SA index proceed by applying Hadlock and Pierce's coefficients to their own samples [Farre-Mensa, Ljungqvist, 2016].

The higher the value of index, the more constrained a firm is. The agreement among the researchers is to classify the top tercile or fourth and fifth quintiles of firms as constrained and the bottom tercile or first and second quintiles as unconstrained.

In our research, we use the index grouping over quintiles and drop the third quintile to avoid misspecification issue.

Financial flexibility. In the modern literature, there are several definitions of financial flexibility. Based on the previous literature, we chose the measure that is based on excess cash estimates since it is closely correlated with financial flexibility [Hu, Jiang, Lee, 2013; Lee, Moon, 2011; Blau, Fuller, 2008; DeAngelo, DeAngelo, 2006]. Our measure of excess cash is calculated through an optimal cash holdings model to find the required level of cash reserve [Arslan-Ayaydin, Florackis, Ozkan, 2014]. The construction of the equation is made as follow ${ }^{2}$ :

$$
\begin{aligned}
& \text { Cash Holdings }_{i}= \\
& =\beta_{0}+\beta_{1} \text { MTB }_{i}+ \\
& +\beta_{2} \text { Size }_{i}+\beta_{3} \text { CFTA }_{i}+\beta_{4} \text { Lev }_{i}+ \\
& +\beta_{5} \text { NWCTA }_{i}+\beta_{6} \text { CAPEXTA } \\
& + \\
& +\beta_{7} \text { RD }_{i}+\beta_{8} \text { Div }_{i}+\varepsilon_{i},
\end{aligned}
$$

\footnotetext{
2 The model also includes the mean cash-flow standard deviation of firms in the same industry over previous 5 year (INDSIGM) as an additional explanatory variable [Opler et al., 1999]. However, we could not obtain necessary information for firms in our sample and removed this variable from our model. Also, the model is estimated for each year and industry separately, which means that there is no need to control for year and industry dummies in the model.
} 
where $i$ stands for $i$-firm, MTB is the market-to-book ratio, Size is the logarithm of total assets, CFTA is the net income before depreciation and amortization over book value of total assets, $L e v$ is total debt over book value of total assets, NWCTA is net working capital over book value of total assets, CAPEXTA is capital expenditure over book value of total assets, $R D$ is the value of R\&D expenses over the total assets and Div is the dummy variable set to one if a firm pays dividends in that year and zero otherwise, $\varepsilon_{i}$ is the residuals. These residuals $\varepsilon_{i}$ of the model are used as a proxy for the excess cash measure. Further, this measure is grouped according to the median value: flexible - higher than median, and inflexible - lower than median.

Based on this measure, we classify firms as flexible and inflexible ones.

\section{$Z D$ choice under different effects}

Leverage definition. We define the book leverage ratio of firm as:

$$
B L_{i t}=\left(D L T T_{i t}+D L C_{i t}\right) / T A_{i t},
$$

where $D L T T$ is the amount of long-term debt exceeding maturity of one year, $D L C$ is the debt in current liabilities, including long-term debt due within one year, $T A$ is the total assets of the firm. The book leverage ratio is defined similarly in most recent capital structure papers [Strebulaev, Yang, 2013; Graham, Leary, 2011; Leary, Roberts, 2010; Lemmon, Zender, 2010]. The choice of denominator is less important in the context of $\mathrm{ZD}$ [Strebulaev, Yang, 2013]. If firms apply the same accounting rules (IFRS or GAAP) there is no need to make adjustments when comparing leverage internationally [Rajan, Zingales, 1995].

$Z D$ and $A Z D$ firms' definition. We define firm as ZD firm in particular year if the outstanding amounts of both short-term debt $(D L C)$ and long-term debt $(D L T T)$ are less than 1\% [Strebulaev, Yang, 2013]. For comparison purposes, we also will calculate the fraction of firms that possess less than $5 \%$ long-term debt in total debt and called them as zero long-term debt entities (LTZD). We are also going to define the second category of firms which can be called as almost zero debt (AZD) firms. These firms possess a marginal debt presence in their capital structure and are classified as AZD if book leverage ratio is less than 5\% [Strebulaev, Yang, 2013].

The further examination of the ZD (AZD) pattern includes more comprehensive set of firm- and country-level variables in the logit regression analysis.

Firm-level effect. The traditional capital structure factors (traditional determinants as: Tangibility, Profitability, Growth opportunities and Size are used as the control variables) are unable to explain the presence of ZD firms that is why we are aiming to evaluate if the ZD (AZD and LTZD) choice is attributable to changes in other firmspecific variables [Bessler et al., 2013]. Firstly, tax provisions are suggested to be a primary factor for CS choices [Fan, Titman, Twite, 2012; De Jong, Kabir, Nguyen 2008]. Due to tax deductions are affected by interest payments, we assume our first hypothesis.

Hypothesis 1. Firms with high tax payments are more likely to be ZD firms and these payments cause positive influence on firm's $Z D$ choice.

Then, perhaps, firms may become debtfree because of tax deductions from non-debt sources [DeAngelo, Masulis, 1980], so we state second hypothesis.

Hypothesis 2. The non-debt tax shield affects $Z D$ choice positively.

Firms with ample cash flow can fund investment opportunities with retained earnings, and thus have less incentive to use debt.

Hypothesis 3. Cash flow has a positive impact on a firm's decision to be debt-free. 
Additionally, low leverage limits the agency costs of debt [Myers, 1977]. Leverage can be very low in cases of agency conflict over the future investment timing and additional debt issuance [Hackbarth, Mauer, 2012]. Becoming the debt-free and mitigating underinvestment problems, we assume the following.

Hypothesis 4. ZD firms to show high cash holdings, and reliance on new equity financing - both measures cause positive impact on ZD choice in the firms' CS policy.

We further consider the dividends payout ratio as a proxy for the degree of asymmetric information. Firms with low dividend ratios are more likely to suffer from high informational costs, hence limited access to the debt markets. Thus we propose next hypothesis.

Hypothesis 5. Proxy variables for asymmetric information are positively related to probability of maintaining a $Z D$ policy.

Without interest, depreciation and amortization expenses, dividends could be used to smooth the earnings of ZD firms. When they are joined with high equity issuances, higher dividends might indicate a mean of establishing a reputation for moderation in expropriating wealth from minority shareholders [Gomes, 2000].

Hypothesis 6. ZD firms make higher dividends payouts and this measure causes positive impact over firms to follow the $Z D$ policy.

A ZD firm's stock return volatility reflects its business risk, and this volatility equals to asset volatility. We use the Altman $\mathrm{Z}$-score as the variable for the business risk measurement.

Hypothesis 7. The high level of assets risk is inherited by $Z D$ firms - the impact of interest is positively related to $Z D$ choice.

Country-level effect. Taking into account possible substantial differences over the countries, it is important to examine country- specific factors in more details. Considering the hypotheses described above we are going to examine the impact of country-level characteristics on the CS choice.

Hypothesis 8. Difference between common law countries and civil law countries among emerging capital markets is influential. We use a dummy variable that takes the value of 1 for firms from a civil law country (and 0 otherwise).

The presence of creditor protection can also affect the CS choice. The Creditor Protection Score (CPS) which has been introduces by [La Porta et al., 1998] with several updates by [Djankov, McLiesh, Shleifer, 2007] has been substituted by the Strength of legal rights index (LRPI) calculated by the World Bank. For the regression analysis, we determine a bankruptcy code dummy variable, which takes the value of 1 if the firm belongs to a country with high creditor protection (LRPI is from second, third and fourth quartiles) and 0 otherwise. ${ }^{3}$

Hypothesis 9. Countries with strong bankruptcy code have more $Z D$ firms than countries with weak creditor protection, thus high level of the creditors protection positively affects the ZD choice.

The development of capital markets has been hindered by the decencies of the country's corporate governance system and can be one of the determinants for firms to follow ZD policy [Nivorozhkin, 2015]. The level of capital market development is usually measured by the market capitalization of listed firms to country's GDP, the amount of credits from financial sector over GDP and the amount of deposits to financial sector over GDP.

Hypothesis 10. The variables which define the development of the country's financial system cause negative effect on firms to follow the $Z D$ policy.

3 The definition of the LRPI construction is presented in the Table 1, and its value for each country from the sample is shown in the Appendix Table A1. 
Staying in the line with related research papers we use GDP per capita growth, and the inflation rate as additional control independent variables in our logistic regression (see Table 1 for definition of variables).

\section{Sample and Data}

\section{Sample construction}

Our research is based on the sample of emerging markets companies. Based on the country classification our sample comprises of all actively traded industrial firms from 21 countries which are classified as emerging markets. ${ }^{4}$ We collect annual balance sheet data, income statement and cash flow statements data and market data of listed firms from the Capital IQ database over the period from 2010 to 2015. All variables are denominated in US dollars. Considering the specific nature of financial and utility firms (Capital IQ classification) we exclude them from our sample. Staying in line with major academic studies, we omit firm-year observations with missing information on total assets, depreciation and amortization, cash, EBIT, retained earnings, earnings from continuous operations (or earnings before extraordinary items), total equity, total shares outstanding and market capitalization. We then winsorize all variables at the $1 \%$ and the $99 \%$ tails not to deal with potential outliers. After all data cleaning steps, our final panel data set includes 6525 industrial firms with a total of 24149 firm-year observations ${ }^{5}$. An overview of all the variables we use in our analysis with a detailed description of construction are shown in Table 1. The list of the countries and their

4 The data has been obtained from the World Bank database. Following the "One China principle", the missed country-level indicators for Taiwan have been taken equal to Chinese ones.

5 The total number of firm-year observations including the lag years is equal to 27150 firm-year observations. institutional characteristics are presented in Appendix Table A1.

We calculate the book leverage as the ratio of the sum of short- and long-term debt to total assets [Devos et al., 2012; Strebulaev, Yang, 2013; Bessler et al., 2013]. ZD observations are firm-year observations with leverage less 1\%, AZD observations are firmyear observations with book leverage less $5 \%$, and LTZD observations are firm-year observations with zero long-term debt. ${ }^{6}$ The Appendix Table A2 provides descriptive statistics for all variables.

The median book leverage ratio is $23.1 \%$ for the full sample, whilst this indicator for constrained firms is around $20.4 \%$ and for flexible firms is around to $21.6 \%$. Being constrained, firms choose around $23.4 \%$ of leverage on average, while being flexible the level of leverage on average rise to $24.5 \%$. This could be a result of being forced to choose lower level of debt in case of financial constraints. Here, the preliminary hypothesis could be derived

Hypothesis 11. The financing constraints (small size and young age due to SA index) are determinants for the CS choice, while the flexibility of financing results in rather larger and older firms.

However, the financially flexible firms on average are riskier, possess higher cash holdings, they are less tangible and profitable comparing to constrained firms. Other variables are in line with expectations and logic as described above.

\section{Results of the econometric models}

The results of the econometric models' analysis follow the abovementioned hypotheses that we structured accordingly in Table 2 .

\footnotetext{
${ }^{6}$ Due to the extremely low level of purely zerodebt and long-term zero debt firms we assume to consider a firm with leverage level less $1 \%$ as zerodebt firm, whilst we assume to consider a firm with the fraction of long-term debt in the total amount of debt less $5 \%$ as zero long-term debt firm.
} 


\section{Variables' definition}

\begin{tabular}{|c|c|}
\hline Variable & Definition and construction methodology \\
\hline \multicolumn{2}{|r|}{ Firm-level variables } \\
\hline Book leverage & Ratio of long- and short-term debt to total book equity \\
\hline Age & Difference between the actual year and a firm's IPO date \\
\hline Size & Natural logarithm of book value of total assets \\
\hline Market-to-book & $\begin{array}{l}\text { Market-to-book ratio is calculated as the sum of total assets and market value of } \\
\text { equity less total stockholders' equity, to total assets }\end{array}$ \\
\hline Tangibility & Ratio of fixed assets to book value of total assets \\
\hline Profitability & Ratio of operating income before depreciation to book value of total assets \\
\hline Payout ratio & Ratio of the sum of cash dividends and share repurchases to book value of total assets \\
\hline Equity issuances & Ratio of total equity issuances to book value of total assets \\
\hline Taxes & Ratio of income taxes paid to total book value of total assets \\
\hline Non-debt tax shield & Ratio of depreciation and amortization to book value of total assets \\
\hline Cash holdings & Ratio of cash equivalents to book value of total assets \\
\hline Business risk & $\begin{array}{l}\text { Altman Z-score - a credit-strength test that gauges a publicly traded manufacturing } \\
\text { company's likelihood of bankruptcy (source: S\&P Capital IQ database) }\end{array}$ \\
\hline Payout dummy & $\begin{array}{l}\text { Dummy variable that takes the value of } 1 \text { if a firm has a payout ratio greater than } \\
\text { zero in a given year (and } 0 \text { otherwise). }\end{array}$ \\
\hline Cash flow & $\begin{array}{l}\text { Value of cash flow as the sum of earnings from continuous operations and deprecia- } \\
\text { tion and amortization to book assets }\end{array}$ \\
\hline $\begin{array}{l}\text { Growth } \\
\text { opportunities }\end{array}$ & $\begin{array}{l}\text { The ratio of growth opportunities is calculated as the sum of market capitalization } \\
\text { and total debt to book assets }\end{array}$ \\
\hline$R \& D$ & Ratio of research and development expenses to book a value of total assets \\
\hline $\begin{array}{l}\text { Capital } \\
\text { expenditures }\end{array}$ & Ratio of capital expenditures to book value of total assets \\
\hline \multicolumn{2}{|r|}{ Country-level variables } \\
\hline Deposits & $\begin{array}{l}\text { Demand, time and saving deposits in deposit money banks and other financial institu- } \\
\text { tions as a share of GDP. See Table A1 for the mean value in all countries (Source: } \\
\text { World Bank) }\end{array}$ \\
\hline Credits & $\begin{array}{l}\text { Domestic credit provided by the financial sector includes all credit to various sectors } \\
\text { on a gross basis to the GDP. See Table A1 for the mean value in all countries (Source: } \\
\text { World Bank) }\end{array}$ \\
\hline Market value & $\begin{array}{l}\text { The share price times the number of shares outstanding (including their several } \\
\text { classes) for listed domestic companies. Investment funds, unit trusts, and companies } \\
\text { whose only business goal is to hold shares of other listed companies are excluded. } \\
\text { Data are end of year values. See Table A1 for the mean value in all countries (Source: } \\
\text { World Bank) }\end{array}$ \\
\hline Inflation rate & $\begin{array}{l}\text { Measured by the consumer price index reflects the annual percentage change in the } \\
\text { cost to the average consumer of acquiring a basket of goods and services that may be } \\
\text { fixed or changed at specified intervals, such as yearly. See Table A1 for the mean } \\
\text { value in all countries (Source: World Bank) }\end{array}$ \\
\hline GDP per capita & $\begin{array}{l}\text { Annual real GDP per capita in the country. See Table A1 for the mean value in all } \\
\text { countries (Source: World Bank) }\end{array}$ \\
\hline Legal system & $\begin{array}{l}\text { Dummy variable that equals } 0 \text { for countries with a common law system, and } 1 \text { for } \\
\text { countries with a civil law system. See Table A1 for an overview of the legal system } \\
\text { in all countries (Source: International Monetary Fund) }\end{array}$ \\
\hline
\end{tabular}


Table 1 (continued)

\begin{tabular}{c|l}
\hline \multicolumn{1}{c}{ Variable } & \multicolumn{1}{c}{ Definition and construction methodology } \\
\hline Bankruptcy code & $\begin{array}{l}\text { Dummy variable that equals 1 if the country has a high legal rights protection score } \\
\text { (LRPI belongs to second, third and fourth quartiles), and 0 - otherwise. Strength of } \\
\text { legal rights index measures the degree to which collateral and bankruptcy laws protect } \\
\text { the rights of borrowers and lenders and thus facilitate lending. The index ranges from } \\
\text { 0 to 12, with higher scores indicating that these laws are better designed to expand } \\
\text { access to credit. See Table A1 for an overview of the bankruptcy codes in all countries } \\
\text { (Source: World Bank) }\end{array}$ \\
\hline
\end{tabular}

Despite our models tested all the hypotheses, we are focusing on our main findings respectively to corresponding hypotheses.

\section{Multivariate firm-level analysis}

The Table 3 shows the results of our binary choice (probit) regression models. The dependent variable takes the value of 1 if a firm is ZD, AZD and LTZD in a given year (and 0 otherwise). The explanatory variables used in the models are one-year lagged to avoid endogeneity problems. To control country and industry time effect we use the country and industry fixed effects. The columns $1,3,5$ and 7 report the results of firm-level specific characteristics, whilst the column 1 shows the result of model with control variables only, the column 3 represents the extended model, the column 5 includes the dummy variable of financially constrained and financially flexible measures, and the column 7 provides the results for the extended model with dummy variables that include firms belongingness to constrained flexible or unconstrained flexible, or constrained inflexible, or unconstrained inflexible type.

The Table 3 also provides the economic implication by providing the average marginal effects in probability that a firm follows a ZD, AZD or LTZD policy as an answer for change in an explanatory variable or the change from zero to one for a dummy variable. We compute the probit models for three panels: the ZD firms, the AZD firms and the LTZD firms to define the determinants causing these firms to follow ZD, AZD or LTZD policy respectively.

There are several major results that should be highlighted.

First of all, the negative intercepts for the all three panels imply that these firms are less common than debt (levered) firms. The usage of standard CS determinants for the estimations ZD pattern provides worse results comparing to the extended models for the all three panels according to the pseudo $R$-squared value.

Secondly, we examined the set of internal and external factors that influence the choice of zero leverage policy. It should be specified, that in most cases the determinants are very close for zero and almost zero panels whereas the results differ significantly for long-term debt absence. This could be explained by the fact, that on emerging markets total debt prove to show more reliable results since even short-term debt act could act for long-term purposes. Thus, total debt helps more in describing the capital structure choice of a firm, whereas the results on long-term debt choice help with the interpretation on the firm's creditworthiness, flexibility and constraints existence.

Within the set of internal characteristics, the following results are worth discussing.

The positive coefficient of the income taxes paid for the panel A and B (ZD and AZD firms respectively) proves that firms with higher tax payments are more likely to be debt-free (Hypothesis 1), whereas this coefficient is statistically insignificant for 
The tested hypotheses

\begin{tabular}{|c|c|c|}
\hline Hypothesis & Description & $\begin{array}{c}\text { Result obtained } \\
\text { (dependency pattern) }\end{array}$ \\
\hline Hypothesis 1 & $\begin{array}{l}\text { Firms with high tax payments are more likely to } \\
\text { be ZD firms and these payments cause positive } \\
\text { influence on firm's ZD choice }\end{array}$ & $\begin{array}{l}\text { Accepted, positive and statistically sig- } \\
\text { nificant dependency for ZD and AZD } \\
\text { choices }\end{array}$ \\
\hline Hypothesis 2 & $\begin{array}{l}\text { The non-debt tax shield affects ZD choice posi- } \\
\text { tively }\end{array}$ & $\begin{array}{l}\text { Mostly not accepted, not proved under } \\
\text { statistically significant levels, hence } \\
\text { revealed the negative dependency for } \\
\text { LTZD choice }\end{array}$ \\
\hline Hypothesis 3 & $\begin{array}{l}\text { Cash flow has a positive impact on a firm's deci- } \\
\text { sion to be debt-free }\end{array}$ & $\begin{array}{l}\text { Accepted, proved for ZD and AZD } \\
\text { choices }\end{array}$ \\
\hline Hypothesis 4 & $\begin{array}{l}\text { ZD firms to show high cash holdings, and reli- } \\
\text { ance on new equity financing - both measures } \\
\text { cause positive impact on ZD choice in the firms' } \\
\text { CS policy }\end{array}$ & $\begin{array}{l}\text { Cash holdings proved our expectations } \\
\text { while the equity issuance showed nega- } \\
\text { tive impact without necessary statisti- } \\
\text { cal significance }\end{array}$ \\
\hline Hypothesis 5 & $\begin{array}{l}\text { We assume that proxy variables for asymmetric } \\
\text { information are positively related to probability } \\
\text { of maintaining a } \mathrm{ZD} \text { policy }\end{array}$ & $\begin{array}{l}\text { Negative statistical significant impact } \\
\text { only for AZD choice }\end{array}$ \\
\hline Hypothesis 6 & $\begin{array}{l}\text { ZD firms make higher dividends payouts and this } \\
\text { measure causes positive impact over firms to fol- } \\
\text { low the ZD policy }\end{array}$ & $\begin{array}{l}\text { The negative dependency for ZD and } \\
\text { AZD, while opposite for LTZD; hypoth- } \\
\text { esis have not reached the required sta- } \\
\text { tistical significance level }\end{array}$ \\
\hline Hypothesis 7 & $\begin{array}{l}\text { The high level of assets risk is inherited by ZD } \\
\text { firms - the impact of interest is positively re- } \\
\text { lated to ZD choice }\end{array}$ & $\begin{array}{l}\text { Accepted, the positive and statistically } \\
\text { significant result for all panels }\end{array}$ \\
\hline Hypothesis 8 & $\begin{array}{l}\text { Difference between common law countries and } \\
\text { civil law countries among emerging capital mar- } \\
\text { kets is influential }\end{array}$ & No significant linkage obtained \\
\hline Hypothesis 9 & $\begin{array}{l}\text { Countries with strong bankruptcy code have more } \\
\text { ZD firms than countries with weak creditor pro- } \\
\text { tection, thus high level of the creditors protection } \\
\text { positively affects the ZD choice }\end{array}$ & $\begin{array}{l}\text { Accepted for LTZD. The results for } \\
\text { other measures are insignificant }\end{array}$ \\
\hline Hypothesis 10 & $\begin{array}{l}\text { The variables which define the development of the } \\
\text { country's financial system cause negative effect } \\
\text { on firms to follow the ZD policy }\end{array}$ & $\begin{array}{l}\text { Mostly accepted, but some variables have } \\
\text { not showed necessary statistically sig- } \\
\text { nificance level }\end{array}$ \\
\hline Hypothesis 11 & $\begin{array}{l}\text { The financing constraints (small size and young } \\
\text { age due to SA index) are determinants for the CS } \\
\text { choice, while the flexibility of financing results in } \\
\text { rather larger and older firms }\end{array}$ & $\begin{array}{l}\text { Partially accepted regarding the impact } \\
\text { of financial flexibility }\end{array}$ \\
\hline
\end{tabular}

the panel C: the LTZD firms. Increase in the income tax ratio to total assets among the ZD and AZD firms results in the around $10 \%$ and $40 \%$ increase in probability to follow the ZD and the AZD policy respective- ly. Switching to the LTZD firms the overall result of the income tax ratio shows the statistical insignificance.

The negative coefficients on profitability for the ZD and the AZD firms' panels (co- 
lumns 3,5 and 7) shows that the less profitable firms are more likely to follow the debtfree (around 2\% marginal effect) and almost debt-free (around 15\% marginal effect) policies. The profitability measure is insignificant for the LTZD choice again supporting the idea, that firms consider long term debt together with the short-term debt for strategic purposes, thus, the one part of the total debt cannot be explained by the same determinants but rather explain the determinants of longterm debt accessibility. To prove that argument, we see the significance of size (the greater the size, the more probable for the firm to get a long-term debt which decreases the probability of zero-debt), tangibility (the same interpretation) and business risk (the greater the risk, the greater the probability of zero-debt).

As for the ZD and AZD, we obtain another set of major factors, mostly responsible for the level of unpredictability of the future outcomes: growth opportunities, profitability, cash holdings and business risk. Particularly, firms that follow ZD and AZD policies have lower growth opportunities, higher market-to-book ratios. Firms following the AZD and LTZD policies are smaller, while the later ones are also older (the Age variable shows insignificant level for panels A: the ZD firms and panel B: the AZD firms, while the direction of impact for the panel $\mathrm{A}$ is negative and for the panel B positive). At the same time, the positive coefficients cash holdings (for the ZD and AZD firms) can support our debt choice argument based on agency costs (Hypothesis 4). The increase of cash holdings to avoid underinvestment issues [Opler et al., 1999] shows the highest significance: a change in cash holdings is related to an increase in the probability to become $\mathrm{ZD}$ or $\mathrm{AZD}$ in the range of $4 \%$ and $17 \%$ for the ZD and AZD firms respectively. Moreover, the positive cash flow has a positive impact over the ZD and AZD choice (Hypothesis 3). We found out that equity issues demonstrate negative impact over AZD choice - the contradiction of the pecking order theory - the firms use equity instead of debt for financing, rather than recapitalization (Hypothesis 4).

A payout ratio shows statistical insignificance for all three groups (Hypothesis 6 ), whereas the dividends payout dummy variable negatively affects the AZD policy choice (Hypothesis 5) and does not support out hypothesis regarding the positive impact of asymmetric information proxy. Additionally, the high asset risk of firms from all panels show that the riskier firms are more likely to choose ZD, AZD and LTZD policies (Hypothesis 7) - these findings are consistent with the inference that the risky firms are constrained to use debt [Bolton, Freixas, 2000].

We see from adding the financial constraints and financial flexibility dummies (column 7), that the ZD choice is more common among unconstrained inflexible firms, the AZD choice is more common among unconstrained both flexible and inflexible, and constrained inflexible firms. Thus, we state that the inflexibility is the dominant motive to follow the ZD. And AZD. Still, when we consider LTZD choice, it is more common only for constrained inflexible firms (Hypothesis 11). From that observation we could state that constrained firms either try to rely on short-term debt in the volume that exceeds $5 \%$ of total capital if they are flexible or they are forced to stick to longterm zero debt policy if they are both inflexible and constrained. Thus, their choice of strategy is also to a large extent dependent on flexibility. Overall, we could summarize that the firm's choice of zero-leverage is not always necessarily a forced case of financial constraints. Even if the firms are not constrained, they tend to keep the flexibility.

\section{Multivariate country-level analysis}

The use of country fixed effects in our probit models in Table 3 (columns 1, 3, 5 and 7) 


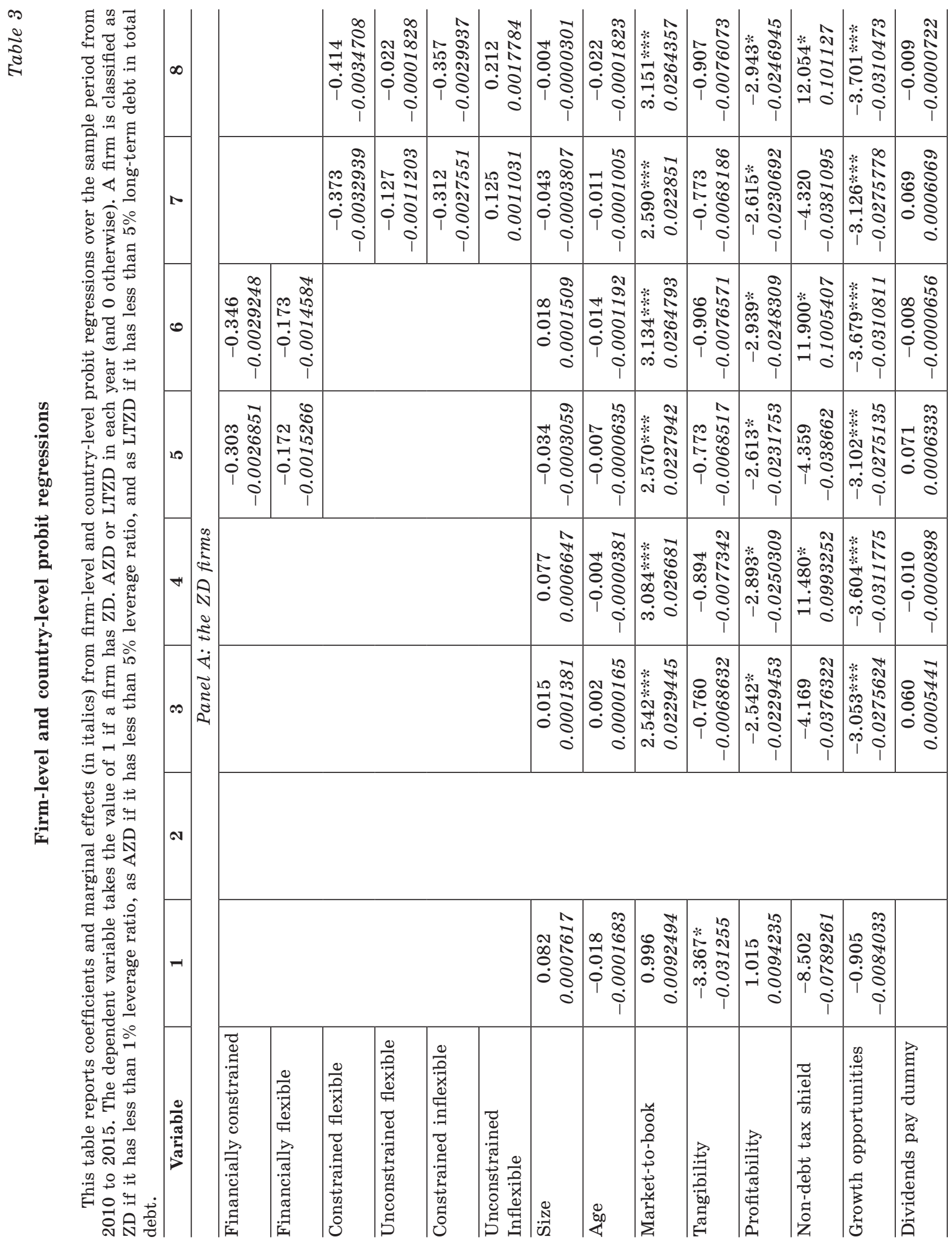

RMJ 16 (3): 407-434 (2018) 


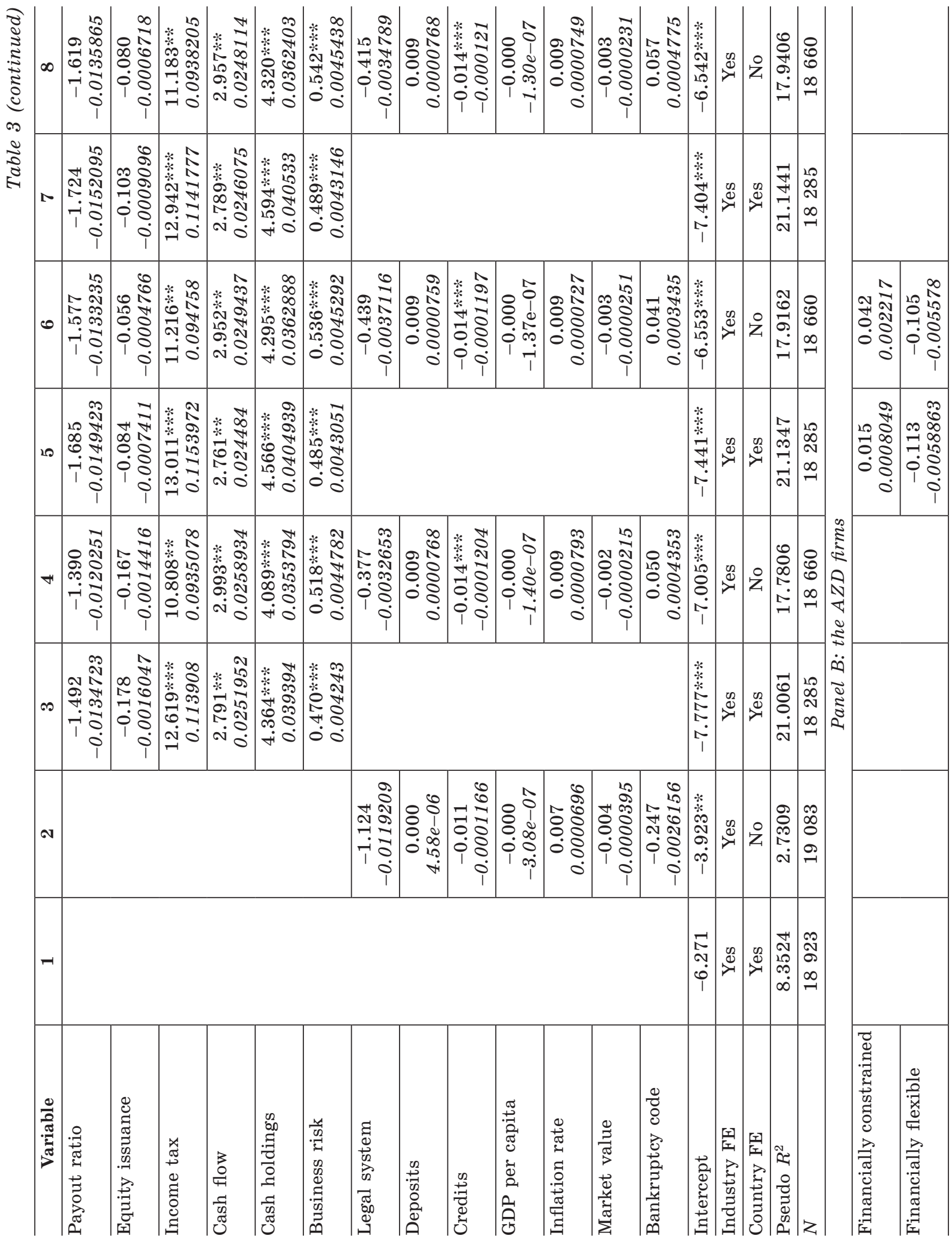




\begin{tabular}{|c|c|c|c|c|c|c|c|c|c|c|c|c|c|c|c|c|c|}
\hline$\infty$ & $\begin{array}{ll} & 7 \\
0 & 7 \\
0 & 0 \\
-1 & 8 \\
0 & 8 \\
1 & \vdots \\
& 0\end{array}$ & 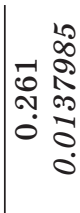 & 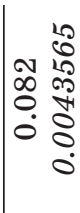 & $\begin{array}{rr} & \infty \\
& 0 \\
-1 & 0 \\
0 & 0 \\
-1 & 0 \\
0 & 0 \\
0 & 0 \\
0 & 0\end{array}$ & 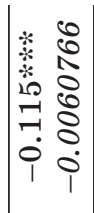 & 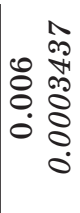 & 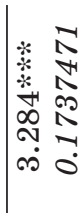 & 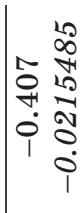 & 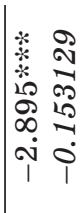 & 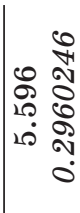 & 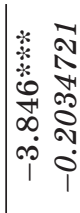 & $\begin{array}{ll} & 1 \\
0 & 0 \\
0 & 1 \\
0 & \infty \\
0 & 0 \\
0 & 0 \\
1 & 0 \\
1 & 0\end{array}$ & 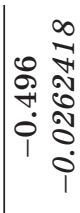 & 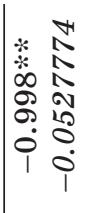 & 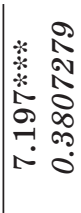 & 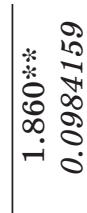 & 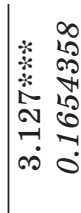 \\
\hline$N$ & 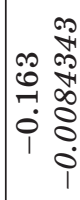 & 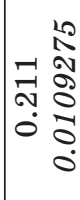 & 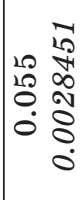 & 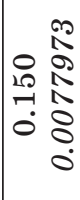 & 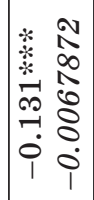 & 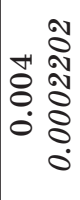 & 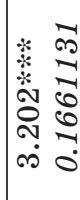 & 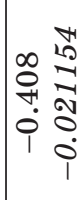 & 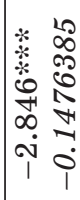 & 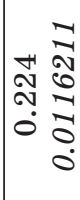 & 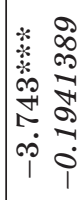 & 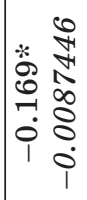 & 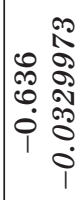 & 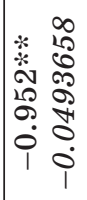 & 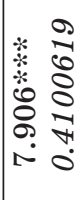 & 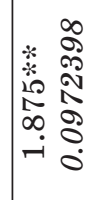 & 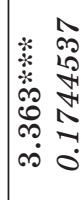 \\
\hline 0 & & & & & $\begin{array}{ll}* & 0 \\
* & 10 \\
* & 10 \\
0 & 10 \\
0 & 0 \\
0 & 8 \\
0 & 0 \\
1 & 0 \\
1 & 0\end{array}$ & $\begin{array}{rl} & 0 \\
& 12 \\
0 & 2 \\
0 & 0 \\
0 & 0 \\
0 & 0 \\
0\end{array}$ & 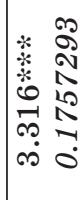 & 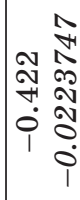 & 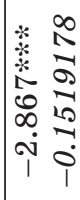 & 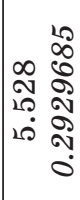 & 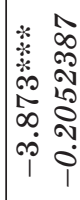 & 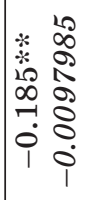 & 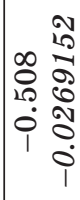 & 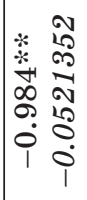 & 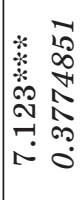 & $\begin{array}{lll} & 0 \\
* & 2 \\
* & 0 \\
\infty & 2 \\
0 & 2 \\
-1 & 0\end{array}$ & 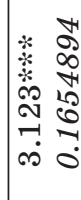 \\
\hline 10 & & & & & 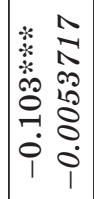 & 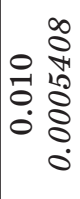 & 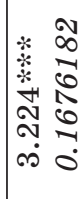 & 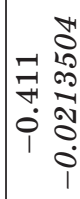 & 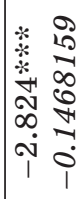 & 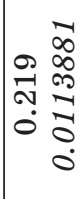 & 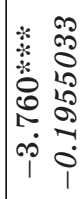 & 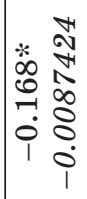 & 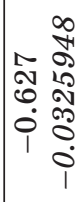 & 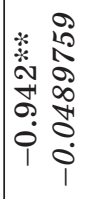 & 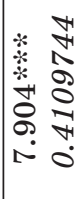 & 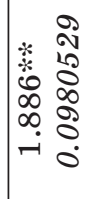 & 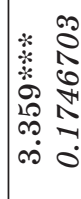 \\
\hline$\nabla$ & & & & & 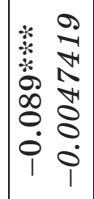 & 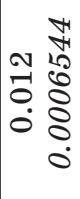 & 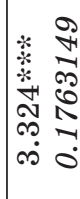 & 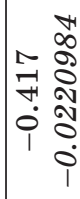 & 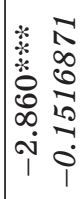 & 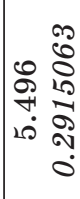 & 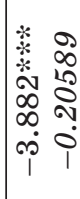 & $\begin{array}{ll}* & - \\
* & 0 \\
10 & \infty \\
\infty & 8 \\
-1 & 8 \\
0 & 0 \\
1 & 0\end{array}$ & 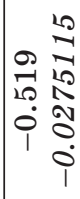 & 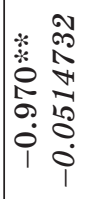 & 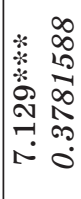 & 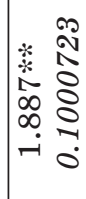 & 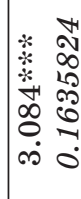 \\
\hline$\infty$ & & & & & 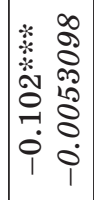 & 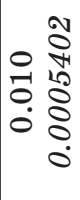 & 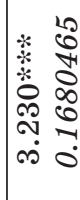 & 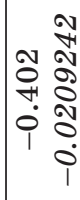 & 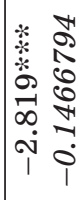 & $\mid \begin{array}{ll} & 10 \\
& 0 \\
8 & 0 \\
0 & 0 \\
-1 & 0 \\
0 & 0 \\
0 & 0\end{array}$ & $\begin{array}{ll}* & 7 \\
\cdots & 0 \\
0 & 0 \\
0 & 2 \\
0 & 2 \\
10 & 0 \\
1 & 0\end{array}$ & $\begin{array}{ll} & 10 \\
* & 0 \\
0 & 0 \\
0 & 0 \\
-1 & 0 \\
0 & 0 \\
1 & 0 \\
1 & 0\end{array}$ & 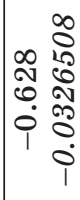 & 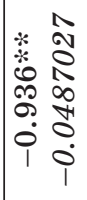 & 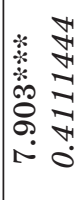 & 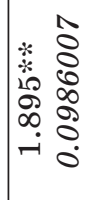 & 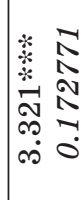 \\
\hline N & & & & & & & & & & & & & & & & & \\
\hline-1 & & & & & 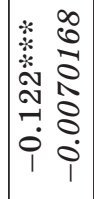 & 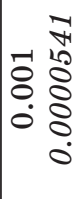 & 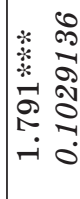 & 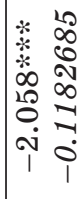 & 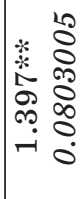 & 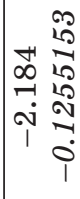 & 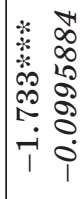 & & & & & & \\
\hline 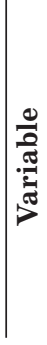 & 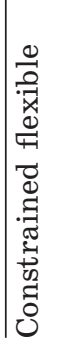 & 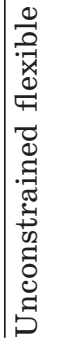 & 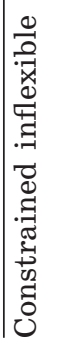 & 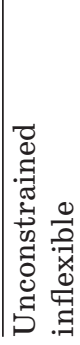 & 古 & $\underset{\$}{\infty}$ & 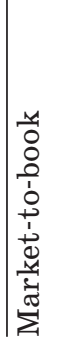 & 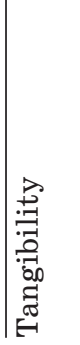 & 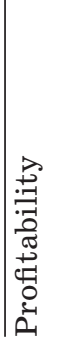 & 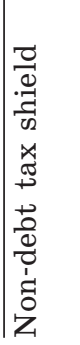 & 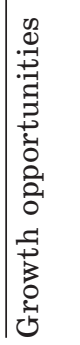 & 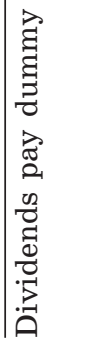 & 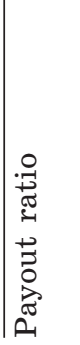 & 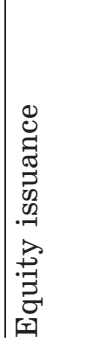 & 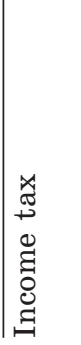 & $\begin{array}{l}3 \\
0 \\
0 \\
0 \\
-1 \\
01 \\
0 \\
0 \\
0\end{array}$ & 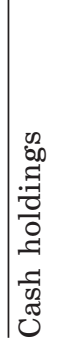 \\
\hline
\end{tabular}




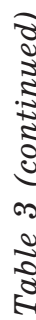

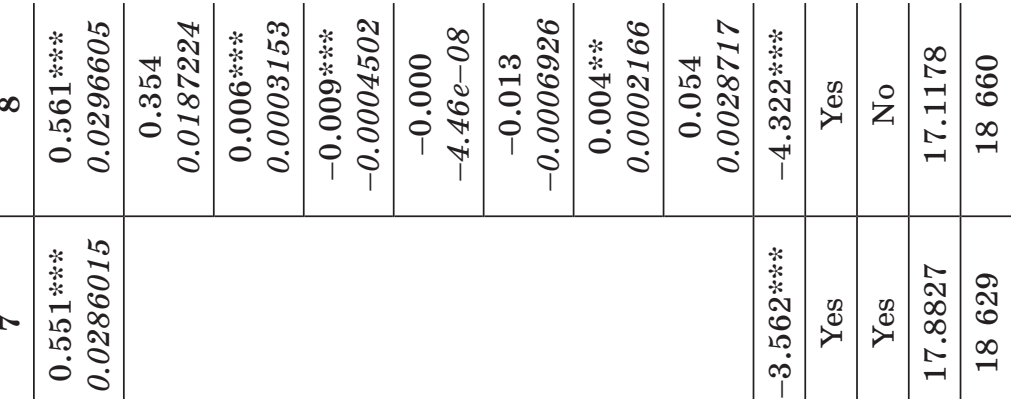

\begin{tabular}{|c|c|c|c|c|}
\hline & & 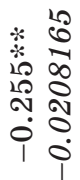 & 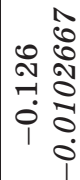 & $\begin{array}{ll} & 2 \\
0 & 2 \\
0 & 0 \\
0 & 0 \\
0 & 8 \\
0 & 0 \\
& 0\end{array}$ \\
\hline & & 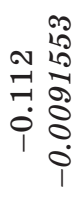 & 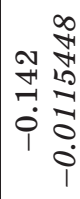 & 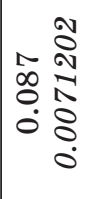 \\
\hline 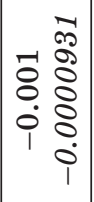 & 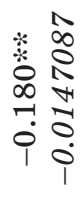 & & & \\
\hline 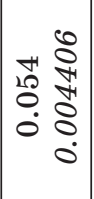 & 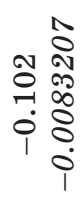 & & & \\
\hline
\end{tabular}

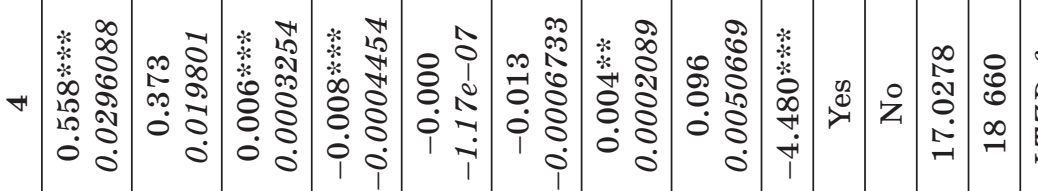

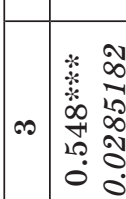

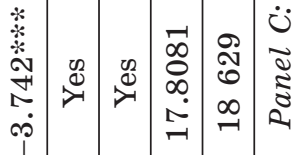

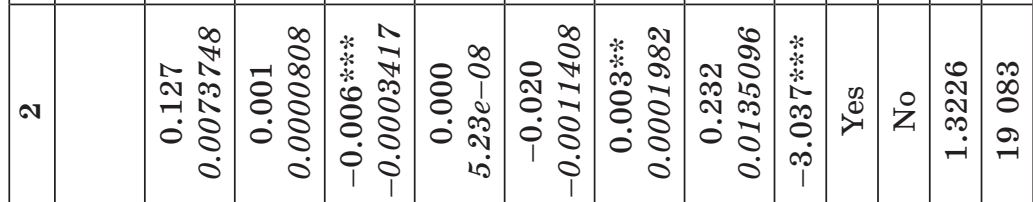

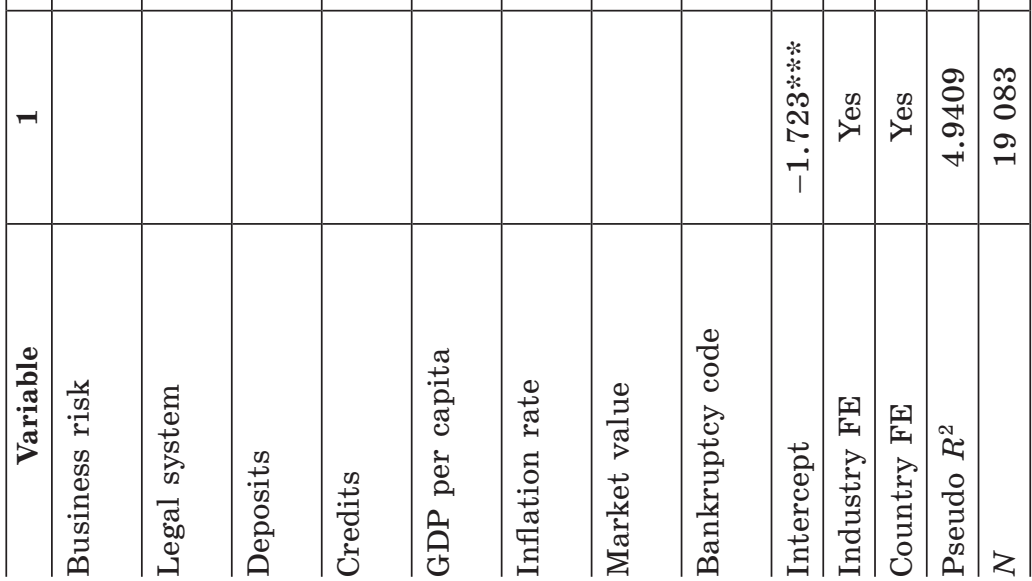

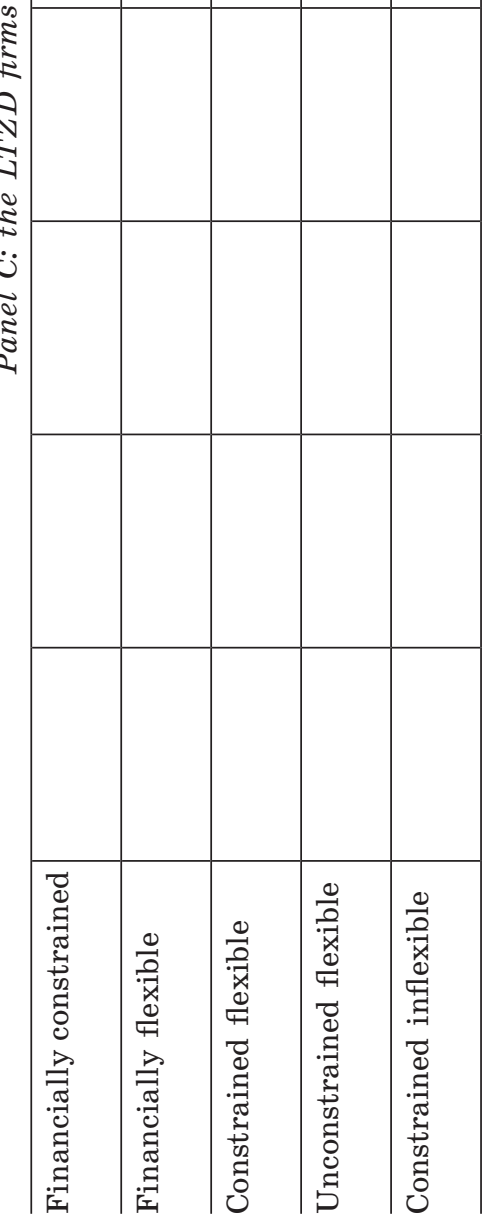

RMJ 16 (3): 407-434 (2018) 


\begin{tabular}{|c|c|c|c|c|c|c|c|c|c|c|c|c|c|c|c|}
\hline$\infty$ & $\begin{array}{ll} & 1 \\
& 10 \\
0 & 0 \\
0 & 8 \\
0 & 8 \\
0 & 0 \\
1 & 0 \\
& 0\end{array}$ & 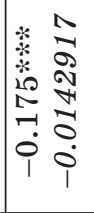 & 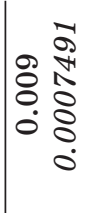 & $\begin{array}{ll}0 & 0 \\
8 & 0 \\
0 & 0 \\
-1 & 8 \\
0 & 0 \\
0 & 0\end{array}$ & 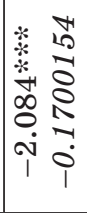 & 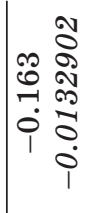 & 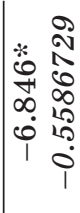 & 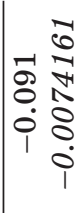 & 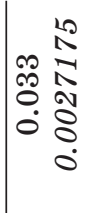 & 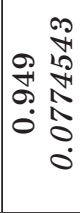 & 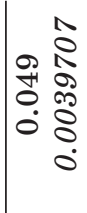 & 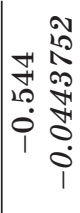 & 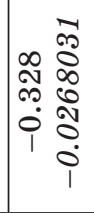 & 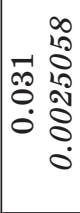 & 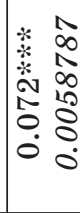 \\
\hline$N$ & 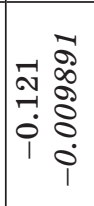 & 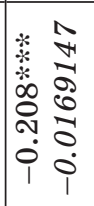 & 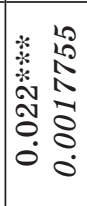 & 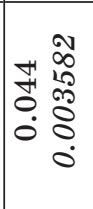 & 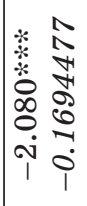 & $\begin{array}{ll} & \infty \\
& \infty \\
20 & 0 \\
0 & N \\
0 & 1 \\
0 & 0 \\
0 & 0 \\
0 & 0\end{array}$ & 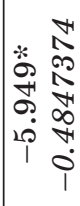 & 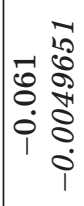 & 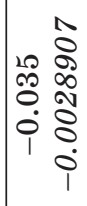 & 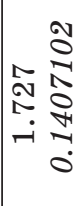 & $\begin{array}{ll} & 0 \\
0 & 2 \\
0 & 0 \\
0 & 0 \\
0 & 0 \\
1 & 0\end{array}$ & 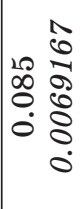 & 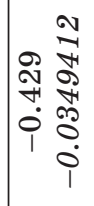 & 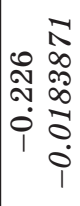 & 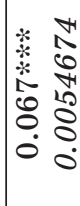 \\
\hline 0 & & 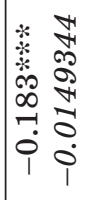 & $\begin{array}{ll} & 2 \\
0 & 8 \\
0 & 0 \\
0 & 8 \\
0 & 8 \\
0 & 0 \\
& 0\end{array}$ & $\begin{array}{ll} & \bar{\infty} \\
0 & 0 \\
0 & 2 \\
-1 & \infty \\
0 & 0 \\
0 & 0 \\
0\end{array}$ & 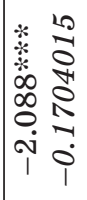 & 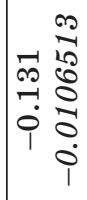 & 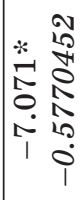 & 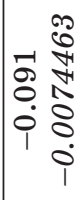 & 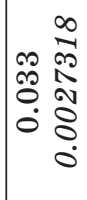 & 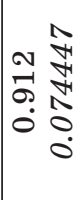 & 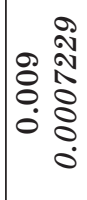 & $\begin{array}{ll} & 0 \\
\infty & 1 \\
0 & 0 \\
0 & 1 \\
0 & 0 \\
0 & 0 \\
1 & 0\end{array}$ & 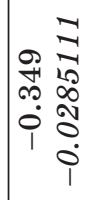 & 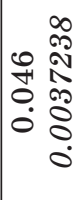 & 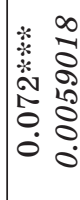 \\
\hline 10 & & 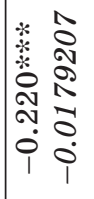 & 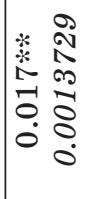 & 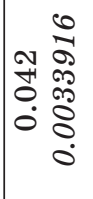 & 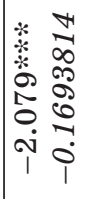 & 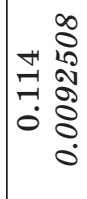 & 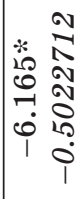 & 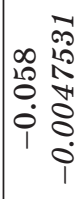 & 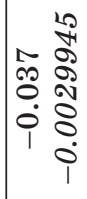 & 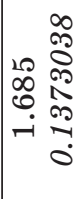 & 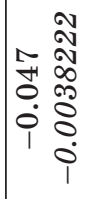 & $\begin{array}{rl} & \stackrel{\infty}{0} \\
= & 1 \\
0 & 0 \\
0 & 0 \\
0 & 0 \\
1 & 0 \\
1\end{array}$ & $\begin{array}{cc} & 2 \\
0 & 0 \\
10 & 0 \\
1 & 0 \\
1 & 0 \\
0 & 0 \\
1 & 0 \\
& 0\end{array}$ & 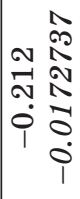 & $\begin{array}{ll}* & 1 \\
* & 0 \\
0 & 10 \\
0 & 0 \\
0 & 0 \\
0 & 0 \\
0 & 0\end{array}$ \\
\hline$\nabla$ & & 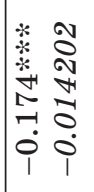 & 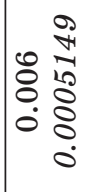 & 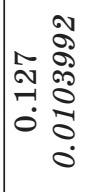 & 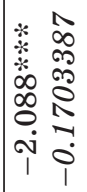 & 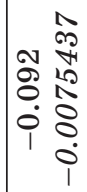 & $\begin{array}{ll} & 1 \\
* & 0 \\
0 & 0 \\
0 & 0 \\
1 & 0 \\
& 0 \\
1 & 0 \\
1 & 0\end{array}$ & $\begin{array}{rl} & 2 \\
8 & \stackrel{N}{2} \\
0 & 0 \\
-1 & \infty \\
0 & 0 \\
1 & 0 \\
0 & 1\end{array}$ & 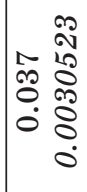 & 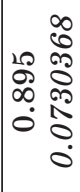 & $\begin{array}{rr} & 2 \\
& 0 \\
0 & 2 \\
0 & 0 \\
0 & 0 \\
0 & 0 \\
0 & 0\end{array}$ & 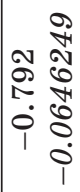 & 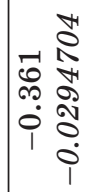 & $\begin{array}{rr} & 0 \\
\infty & 0 \\
0 & 0 \\
0 & 0 \\
0 & 0 \\
0 & 0 \\
1 & 0 \\
0 & 1\end{array}$ & 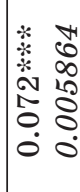 \\
\hline$\infty$ & & 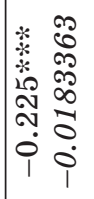 & 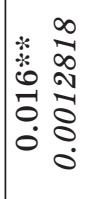 & 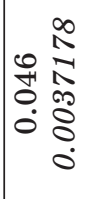 & 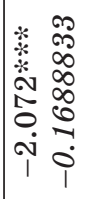 & 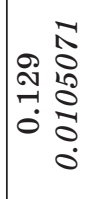 & 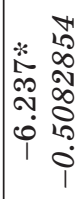 & $\mid$\begin{tabular}{ll} 
& 12 \\
\hdashline & 7 \\
0 & 2 \\
0 & 0 \\
0 & 0 \\
1 & 0 \\
1 & 1
\end{tabular} & 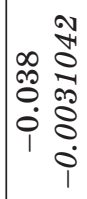 & 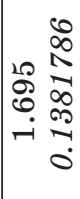 & 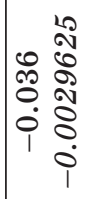 & $\begin{array}{ll} & \infty \\
& 1 \\
5 & 10 \\
0 & 1 \\
0 & 0 \\
0 & 0 \\
1 & 0 \\
& 1\end{array}$ & 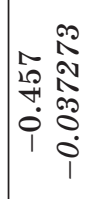 & 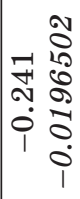 & 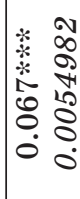 \\
\hline $\boldsymbol{N}$ & & & & & & & & & & & & & & & \\
\hline-1 & & 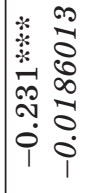 & 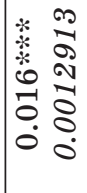 & 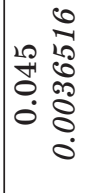 & 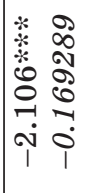 & 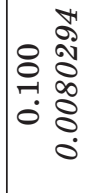 & 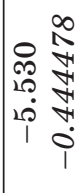 & 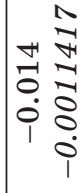 & & & & & & & \\
\hline 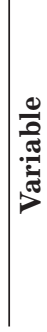 & 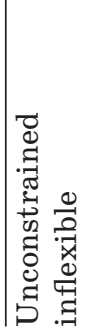 & 离 & 100 & 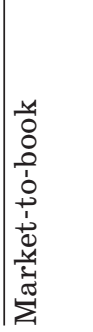 & 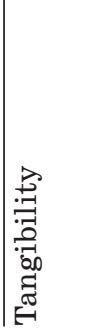 & 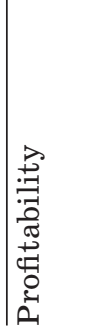 & 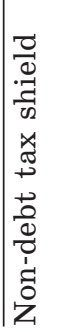 & 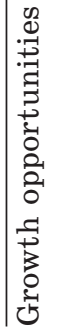 & 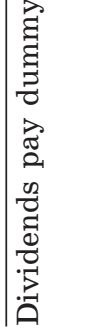 & 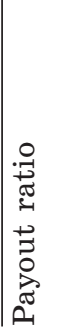 & 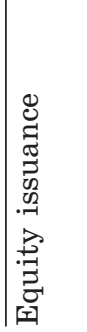 & 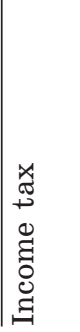 & $\begin{array}{l}3 \\
0 \\
0 \\
4 \\
-1 \\
0 \\
0 \\
0 \\
0\end{array}$ & 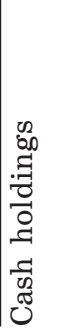 & 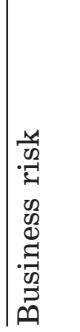 \\
\hline
\end{tabular}




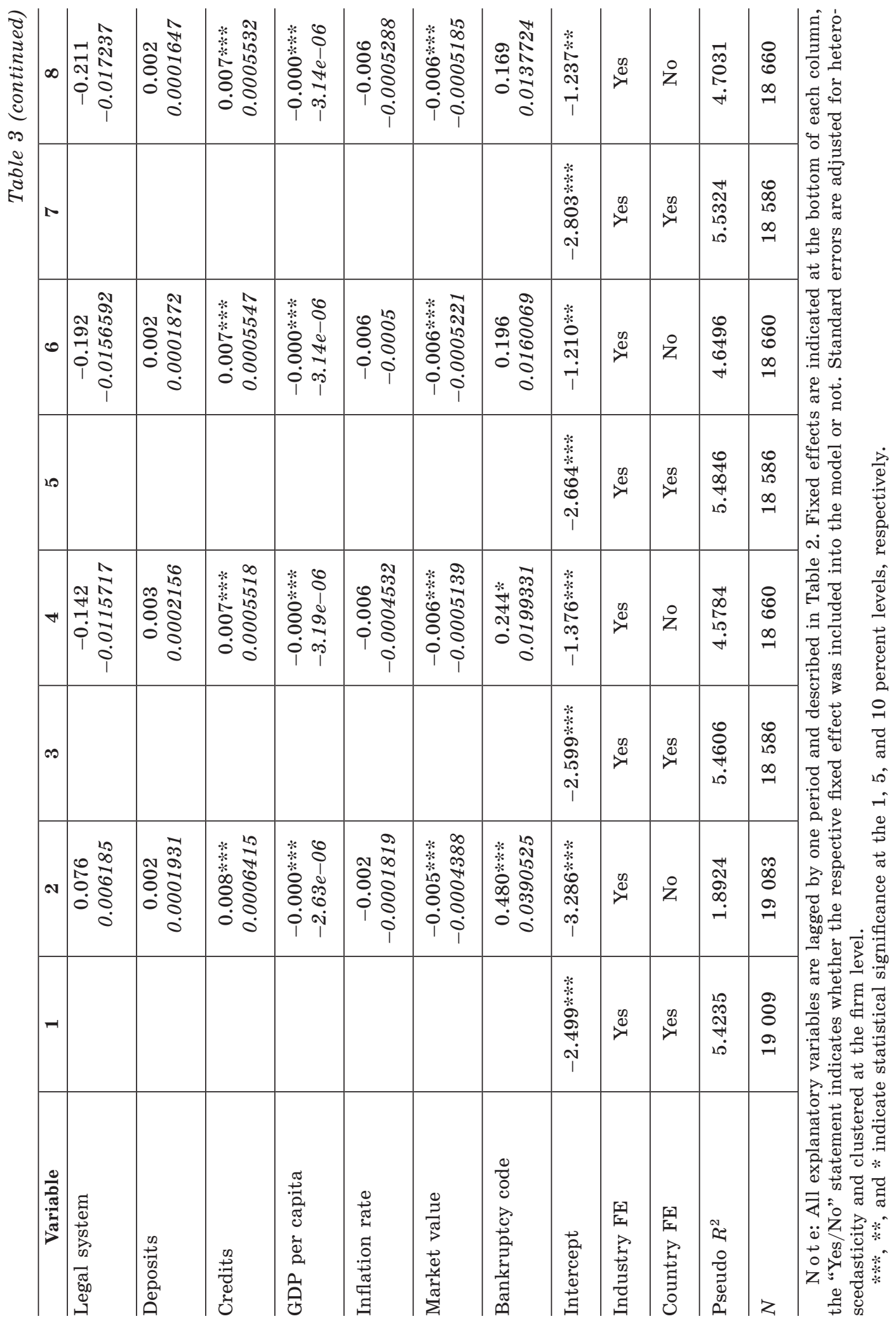


cannot fully explain the increasing percentage of ZD, AZD and LTZD firms. Assuming the considerable cross-sectional variances over the countries, it is necessary to examine countryspecific factors in more detail.

The results of probit regressions involving the set of country-level variables are shown in Table 3 (columns 2, 4, 6 and 8). The explanatory power of just country variables is extremely low (column 2) for the all policies choice. Moreover, including the country-level variables instead of country fixed-effects leads to lower explanatory power of models than ones with only firmlevel characteristics, country and industry fixed-effects meaning that the capital structure decisions are driven mainly by internal factors [Mitton, 2008]. Analyzing the more "powerful" model (column 8) according to pseudo R-squared all the firm-level characteristics remain the same impact as described above. In addition, we find that the level of credits boosts the usage of corporate borrowings for the $\mathrm{ZD}$ and AZD firms, while it results in the LTZD choice. Also, the depth of financial system (deposits variable) together with high market capitalization to country's GDP (market value variable) are positively related to AZD choice (Hypothesis 10). High level of country's financial system development decreases the chance to follow the LTZD policy which goes in line with our hypothesis. Additionally, the high creditors protection (bankruptcy code variable) increases chances to be long-term debt-free firm (Hypothesis 4). The impact is the same for the AZD and ZD firms, but the inference does not show the statistical significance. This finding is close to our argumentation on financial flexibility and constraint. The greater the creditor's protection level is, the tougher are conditions for financially constrained firms. This will influence firms' choice of long-term debt mostly and in case of their inflexible position will most probable lead to zero-leverage choice. This is proved by the results of financial constraints and flexibility measures for these specifications.

\section{Robustness tests}

In order to check the robustness of our firmand country-level results for the AZD firms we check whether the $10 \%$ threshold can be used for the description of AZD firms. ${ }^{7}$

According to the results, the AZD firms are smaller and older, they show higher market-to-book ratio and lower both profitability and growth opportunities. The impact of income tax level, cash flow, cash holdings and asset risk coincide with inference of AZD firms with 5\% leverage threshold.

By adding the country specific variables, we have found the positive influence of inflation rate, market capitalization level and bankruptcy code to follow the AZD policy. Generally, the robustness test proved our previously received results.

\section{Conclusion}

Our study provides insights into the pattern of firms' choices to follow a ZD policy, a behavior that cannot be fully explained by the standard theories of capital structure. The growth of ZD, AZD and LTZD rates of has become a phenomenon not only among developed markets, but emerging ones as well. Our analysis show that the choice of zerodebt policy is mostly driven by internal factors rather than country-level ones, which in term explains why we could observe the ZD phenomenon in a global arena.

The major determinants that influence the ZD policy are represented by growth opportunities, business risk, profitability and cash holdings thus approximating the level of future outcomes predictability and the need for future investments as well.

7 Due to arguments in academic literature regarding the optimal or necessarily required level of leverage for indicating the almost zero-debt pattern. The results of the regressions are omitted, but can be provided upon the request. 
We observe that the leverage ratios based on total debt provide more information on capital structure choice on emerging capital markets in comparison with the longterm debt ratios only. This finding goes in line with the previous literature that is focused on the total debt, supporting our proposition that both long term and shortterm debt could be used for strategic purposes on emerging capital markets [Ghoul et al., 2018].

We considered two major motives for ZD behavior: financial constraints and financial flexibility. We show that financial flexibility motive is true for firms whether they are constrained or not. Thus, firms try to keep the flexibility to have the opportunities for large investments in the future even if they are not forced to stick to the zero-debt policy by the market.

The further analysis should look deeper into the governance mechanisms that could provoke managerial entrenchment motives and ownership issues to consider the risk aversion level of different types of investors. The introduction of these factors on emerging capital markets would decrease the sample available for the investigation but will help with the thorough discussion of other possible motives for becoming a ZD firm.

\section{REFERENCES}

Almeida H., Campello M., Weisbach M.S. 2011. Corporate financial and investment policies when future financing is not frictionless. Journal Corporate Finance 17 (3): 675-693.

Antoniou A., Guney Y., Paudyal K. 2008. The determinants of capital structure: Capital market-oriented versus bank-oriented institutions. Journal of Financial and Quantitative Analysis 43 (1): 59-92.

Arslan-Ayaydin Ö., Florackis C., Ozkan A. 2014. Financial flexibility, corporate investment and performance: Evidence from financial crises. Review of Quantitative Finance and Accounting 42 (2): 211-250.

Bekaert G., Harvey C. R. 2003. Emerging markets finance. Journal of Empirical Finance 10: 3-55.

Benmelech E., Bergman N.K. 2009. Collateral pricing. Journal of Financial Economics 91 (3): 339-360.

Bessler W., Drobetz W., Haller R., Meier I. 2013. The international zero-leverage phenomenon. Journal of Corporate Finance 23: 196-221.

Blau B. M., Fuller K.P. 2008. Flexibility and dividends. Journal of Corporate Finance 14 (2): 133-152.
Bolton P., Freixas X. 2000. Equity, bonds, and bank debt: Capital structure and financial market equilibrium under asymmetric information. Journal of Political Economy 108 (2): 324-351.

Booth L., Aivazian V., Demirguc-Kunt A., Maksimovic V. 2001. Capital structure in developing countries. Journal of Finance 56 (1): 87-130.

Byoun S., Xu Z. 2013. Why do some firms go debt free? Asia-Pacific Journal of Financial Studies 42 (1): 1-38.

Campello M., Giambona E. 2013. Real assets and capital structure. Journal of Financial and Quantitative Analysis 48 (5): 13331370 .

Chen J. J 2004. Determinants of capital structure of Chinese listed companies. Journal of Business Research 57 (12): 1341-1351.

Cook D. O., Tang T. 2010. Macroeconomic conditions and capital structure adjustment speed. Journal of Corporate Finance 16 (1): 73-87.

Cornelli F., Portes R., Schaffer M.E. 1996. Capital Structure of Firms in Central and Eastern Europe. London Business School: London.

Dang V.A. 2011. An Empirical Analysis of Zero-leverage Firms: Evidence from the 
$U K$. Working paper. Manchester Business School: Manchester.

DeAngelo H., DeAngelo L. 2006. The irrelevance of the MM dividend irrelevance theorem. Journal of Financial Economics $\mathbf{7 9}$ (2): 293-315.

DeAngelo H., DeAngelo L. 2007. Capital Structure, Payout Policy, and Financial Flexibility. Working Paper No. FBE 02-06. Marshall School of Business: Los Angeles.

DeAngelo H., DeAngelo L., Whited T.M. 2011. Capital structure dynamics and transitory debt. Journal of Financial Economics 99 (2): 235-261.

DeAngelo H., Masulis R.W. 1980. Leverage and dividend irrelevancy under corporate and personal taxation. Journal of Finance 35 (2): 453-464.

Deb S.G., Banerjee P. 2015. Equity performance of zero-debt firms vis-à-vis their leveraged counterparts. Global Business Review 16 (5): 800-811. https://doi.org/10. $1177 / 0972150915591458$

Delcoure N. 2007. The determinants of capital structure in transitional economies. International Review of Economics \& Finance 16 (3): 400-415.

Devos E., Dhillon U., Jagannathan M., Krishnamurthy S. 2012. Why are firms unlevered? Journal of Corporate Finance 18 (3): 664-682.

Diamond D. W. 1991. Monitoring and reputation: The choice between bank loans and directly placed debt. Journal of Political Economy 99 (4): 689-721.

Djankov S., McLiesh C., Shleifer A. 2007. Private credit in 129 countries. Journal of Financial Economics 84 (2): 299-329.

Easterbrook F.H. 1984. Two agency-cost explanations of dividends. American Economic Review 74 (4): 650-659.

Fama E. F., French K. R. 2002. Testing tradeoff and pecking order predictions about dividends and debt. Review of Financial Studies 15 (1): 1-33.

Fama E.F., French K.R. 2005. Financing decisisons: Who issues stock? Journal of Financial Economics 76 (3): 549-582.
Fan J.P. H., Titman S., Twite G. 2012. An international comparison of capital structure and debt maturity choices. Journal of Financial and Quantitative Analysis $\mathbf{4 7}$ (1): $23-56$.

Farre-Mensa J., Ljungqvist A. 2016. Do measures of financial constraints measure financial constraints? Review of Financial Studies 29 (2): 271-308.

Fischer E.O., Heinkel R., Zechner J. 1989. Dynamic capital structure choice: Theory and tests. Journal of Finance 44 (1): 1940.

Gatchev V.A., Spindt P.A., Tarhan V. 2009. How do firms finance their investments?. The relative importance of equity issuance and debt contracting costs. Journal of Corporate Finance 15 (2): 179-195.

Ghoul S. El, Guedhami O., Kwok C., Zheng X. 2018. Zero-leverage puzzle: An international comparison. Review of Finance 1063-1120. https://doi.org/10.1093/rof/ rfw065

Gomes A. 2000. Going public without governance: Managerial reputation effects. Journal of Finance 55 (2): 615-646.

Graham J.R., Leary M.T. 2011. A review of empirical capital structure research and directions for the future. Annual Review of Financial Economics 3 (November): 309345.

Hackbarth D., Mauer D. C. 2012. Optimal priority structure, capital structure, and investment. Review of Financial Studies $\mathbf{2 5}$ (3): 748-796.

Hadlock C. J., Pierce J.R. 2010. New evidence on measuring financial constraints: Moving beyond the $\mathrm{KZ}$ index. Review of Financial Studies 23 (5): 1909-1940.

Hu C., Jiang W., Lee C. 2013. Managerial flexibility and the wealth effect of new product introductions. Review of Quantitative Finance and Accounting 41 (2): 273-294.

Hussain Q., Nivorozhkin E. 1997. The capital structures of listed companies in Poland. The IMF Working Paper No. 97/175; $1-27$. 
Jensen M.C. 1986. Agency costs of free cash flow, corporate finance, and takeovers. The American Economic 76 (2): 323-329.

Jensen N., Meckling W. 1976. Theory of the firm: Managerial behavior, agency costs, and capital structure. Journal of Financial Economics 3 (4): 305-360.

Jõeveer K. 2006. Sources of Capital Structure: Evidence from Transition Countries. Available at: http://papers.ssrn.com/sol3/papers. cfm?abstract_id=1130306.

De Jong A., Kabir R., Nguyen T.T. 2008. Capital structure around the world: The roles of firm- and country-specific determinants. Journal of Banking and Finance 32 (9): 1954-1969.

De Jong A., Verbeek M., Verwijmeren P. 2012. Does financial flexibility reduce investment distortions? Journal of Financial Research 35 (2): 243-259.

Kaplan N., Zingales L. 1997. Do investmentcash flow sensitivities provide useful measures of financing constraints? Quarterly Journal of Economics 112 (1): 169-215.

King'wara R. 2015. The relationship between financial flexibility and dividend payouts: A case of listed firms in Kenya. European Journal of Business and Management 7 (3): 51-58.

Klapper L. F., Sarria-Allende V., Sulla V. 2002. Small- and Medium-size Enterprise Financing in Eastern Europe. World Bank Policy Research Working Paper No. 2933.

Korteweg A. 2010. The net benefits to leverage. Journal of Finance 65 (6): 2137-2170.

Kraus A., Litzenberger R.H. 1973. A statepreference model of optimal financial leverage. Journal of Finance 28 (4): 911-922.

Lamont O., Polk C., Saá-Requejo J. 2001. Financial constraints and stock returns. Review of Financial Studies 14 (2): 529554.

Leary M.T., Roberts M.R. 2010. The pecking order, debt capacity, and information asymmetry. Journal of Financial Economics 95 (3): 332-355.

Lee H., Moon G. 2011. The long-run equity performance of zero-leverage firms. Mana- gerial Finance 37 (10): 872-889.

Lemmon M. L., Zender J.F. 2010. Debt capacity and tests of capital structure theories. Journal of Financial and Quantitative Analysis 45 (5): 1161-1187.

Marchica M.-T., Mura R. 2010. Financial flexibility, investment ability, and firm value: Evidence from firms with spare debt capacity. Financial Management 39 (4): 13391365.

Meulbroek L. K. 2002. Senior manager's guide to integrated risk management. Journal of Applied Corporate Finance 14 (4): 5670.

Mitton T. 2008. Why have debt ratios increased for firms in emerging markets? European Financial Management 14 (1): 127-151.

Muradoğlu Y.G., Sivaprasad S. 2012. Using firm-level leverage as an investment strategy. Journal of Forecasting 31 (3): 260279.

Myers S.C. 1977. Determinants of corporate borrowing. Journal of Financial Economics 5 (July): 147-175.

Myers S.C., Majluf N.S. 1984. Corporate financing and investment decisions when firms have information that investors do not have. Journal of Financial Economics 13 (2): 187-221.

Nivorozhkin E. 2005. Financing choices of firms in EU accession countries. Emerging Markets Review 6 (2): 138-169.

Nivorozhkin E. 2007. Capital structures in emerging stock markets: The case of Hungary. The Developing Economies 40 (2): 166-187.

Nivorozhkin E. 2015. Black spots' in capital structure studies: The case of non-existing debt. Journal of Corporate Finance Research 9 (6): 5-23.

Opler T. et al. 1999. The determinants and implications of corporate cash holdings. Journal of Financial Economics 52 (1): 3-46.

La Porta R. et al. 1998. Law and finance. Journal of Political Economy 106 (6): 1113-1155.

La Porta R. et al. 2000. Investor protection and corporate governance. Journal of $\mathrm{Fi}^{-}$ nancial Economics 58 (1): 3-27. 
La Porta R., Lopez-De-Silanes F., Shleifer A., Vishny R. 2002. Investor protection and corporate valuation. Journal of Finance 57 (3): 1147-1170.
Rajan G., Zingales L. 1995. What do we know about capital structure? Some evidence from international data. Journal of $\mathrm{Fi}$ nance 50 (5): 1421-1460.

\section{COUNTRIES}

The table summarizes the country-level variables. LRPI denotes the Legal Rights Protection Index from the World Bank database. Mean values are reported for the variables deposits, credits, GDP per

\begin{tabular}{|c|c|c|c|c|c|}
\hline 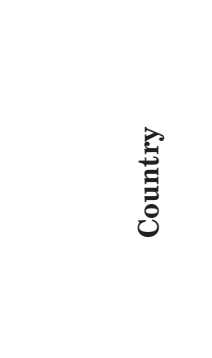 & 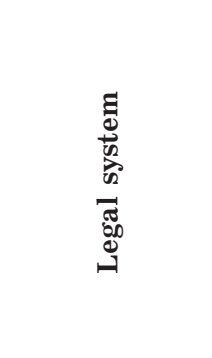 & 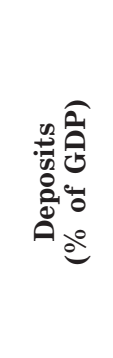 & 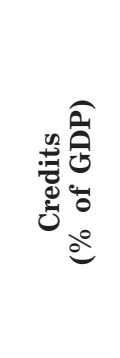 & 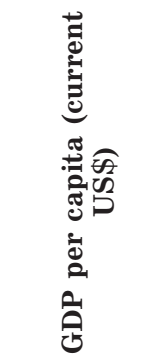 & 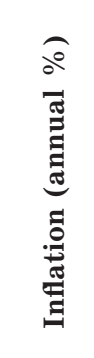 \\
\hline 1 & 2 & 3 & 4 & 5 & 6 \\
\hline Argentina & Civil law & 16.45 & 30.86 & 11879.30 & 15.94 \\
\hline Brazil & Civil law & 53.20 & 99.21 & 11018.84 & 6.22 \\
\hline Bulgaria & Civil law & 64.24 & 65.55 & 7358.97 & 1.68 \\
\hline Chile & Civil law & 44.04 & 113.08 & 13797.86 & 2.62 \\
\hline China & Civil law & 47.03 & 155.85 & 6165.65 & 2.39 \\
\hline Croatia & Civil law & 68.34 & 87.63 & 13433.71 & 1.52 \\
\hline Estonia & Civil law & 53.31 & 82.50 & 17190.17 & 2.00 \\
\hline India & Common law & 62.62 & 75.71 & 1425.17 & 9.17 \\
\hline Indonesia & Civil law & 31.88 & 40.29 & 3316.26 & 5.53 \\
\hline Israel & Common law & 75.40 & 86.17 & 33484.18 & 1.80 \\
\hline Malaysia & Common law & 121.82 & 133.18 & 9955.59 & 2.07 \\
\hline Mexico & Civil law & 26.22 & 47.16 & 9361.52 & 3.93 \\
\hline Peru & Civil law & 31.51 & 21.59 & 5777.48 & 3.01 \\
\hline Poland & Civil law & 49.38 & 66.60 & 13120.37 & 2.07 \\
\hline Romania & Civil law & 32.01 & 43.56 & 8979.25 & 3.61 \\
\hline Russia & Civil law & 40.36 & 42.36 & 12457.71 & 8.88 \\
\hline South Africa & Common law & 59.94 & 180.72 & 6870.06 & 5.49 \\
\hline Taiwan & Civil law & 47.03 & 155.85 & 6165.65 & 2.39 \\
\hline
\end{tabular}

RMJ 16 (3): 407-434 (2018) 
Stiglitz J.E., Weiss A. 1981. Credit rationing in markets with imperfect information. American Economic Review 71 (3): 393-410.
Strebulaev I. A., Yang B. 2013. The mystery of zero-leverage firms. Journal of Financial Economics 109 (1): 1-23.

Initial Submission: December 18, 2017

Final Version Accepted: September 26, 2018

Appendix

Table A1

\section{DESCRIPTION}

capita, inflation rate, market capitalization of listed firms, total tax rate, and the percentage of zero-debt (ZD), almost zero-debt (AZD) and long-term almost zero-debt (LTZD)* firms during the sample period.

\begin{tabular}{|c|c|c|c|c|c|}
\hline 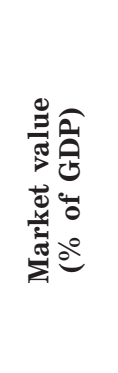 & 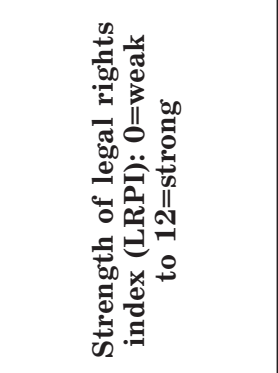 & 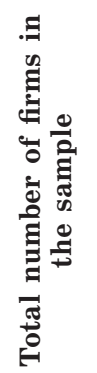 & 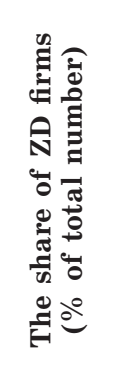 & 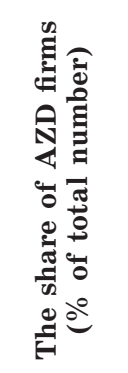 & 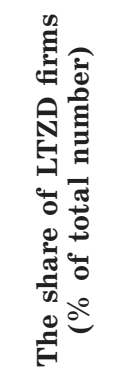 \\
\hline 7 & 8 & 9 & 10 & 11 & 12 \\
\hline 10.52 & 2 - Low LRPI & 27 & $0.00 \%$ & $9.49 \%$ & $1.46 \%$ \\
\hline 50.14 & 2 - Low LRPI & 77 & $5.41 \%$ & $12.21 \%$ & $1.82 \%$ \\
\hline 8.74 & 9 - High LRPI & 24 & $2.10 \%$ & $13.45 \%$ & $10.08 \%$ \\
\hline 111.73 & 4 - Low LRPI & 64 & $0.78 \%$ & $6.23 \%$ & $0.62 \%$ \\
\hline 56.71 & 4 - Low LRPI & 1765 & $0.39 \%$ & $4.49 \%$ & $10.81 \%$ \\
\hline 32.25 & 5 - High LRPI & 37 & $3.62 \%$ & $11.96 \%$ & $5.98 \%$ \\
\hline 7.58 & 7 - High LRPI & 10 & $0.00 \%$ & $2.04 \%$ & $4.08 \%$ \\
\hline 75.90 & 6 - High LRPI & 101 & $3.78 \%$ & $14.60 \%$ & $7.89 \%$ \\
\hline 43.47 & 5 - High LRPI & 236 & $2.05 \%$ & $6.79 \%$ & $7.12 \%$ \\
\hline 75.24 & 6 - High LRPI & 258 & $1.48 \%$ & $5.11 \%$ & $3.95 \%$ \\
\hline 143.46 & 7 - High LRPI & 535 & $0.16 \%$ & $5.49 \%$ & $6.54 \%$ \\
\hline 39.36 & 10 - High LRPI & 42 & $0.79 \%$ & $1.89 \%$ & $1.89 \%$ \\
\hline 48.53 & 8 - High LRPI & 30 & $0.56 \%$ & $3.33 \%$ & $2.00 \%$ \\
\hline 33.51 & 7 - High LRPI & 185 & $1.26 \%$ & $9.64 \%$ & $5.42 \%$ \\
\hline 6.96 & $10-$ High LRPI & 16 & $6.33 \%$ & $13.92 \%$ & $2.53 \%$ \\
\hline 40.63 & 6 - High LRPI & 59 & $7.32 \%$ & $13.18 \%$ & $1.01 \%$ \\
\hline 241.60 & 5 - High LRPI & 118 & $0.00 \%$ & $6.44 \%$ & $4.75 \%$ \\
\hline 56.71 & 4 - Low LRPI & 1138 & $0.00 \%$ & $2.57 \%$ & $7.17 \%$ \\
\hline
\end{tabular}




\begin{tabular}{l|c|c|c|c|c|}
\hline \multicolumn{1}{|c|}{$\mathbf{1}$} & $\mathbf{2}$ & $\mathbf{3}$ & $\mathbf{4}$ & $\mathbf{5}$ & $\mathbf{6}$ \\
\hline Thailand & Civil law & 104.95 & 152.59 & 5543.93 & 1.77 \\
\hline Turkey & Civil law & 49.74 & 78.24 & 10006.20 & 7.74 \\
\hline Vietnam & Civil law & 12.44 & 114.70 & 1704.88 & 7.86 \\
\hline
\end{tabular}

$\mathrm{N}$ o t e: * - due to the extremely low level of purely zero-debt and long-term zero debt firms we assume to considera firm with leverage level less $1 \%$ as zero-debt firm, whilst we assume to consider a firm with the fraction of long-

SUMMARY

\begin{tabular}{|l|c|c|c|c|c|c|}
\hline \multirow{2}{*}{\multicolumn{1}{c|}{ Variable }} & \multicolumn{7}{c|}{ All firms } \\
\cline { 2 - 7 } & $N$ & Mean & SD & Median & Min & Max \\
\hline Leverage & 24149 & 0.254 & 0.248 & 0.231 & 0.000 & 24.773 \\
\hline Size & 24149 & 5.783 & 1.750 & 5.730 & 1.915 & 10.067 \\
\hline Age & 24149 & 10.414 & 6.543 & 10.000 & 0.000 & 35.000 \\
\hline Market-to-book & 24149 & 1.480 & 1.154 & 1.155 & 0.144 & 46.388 \\
\hline Tangibility & 24149 & 0.315 & 0.209 & 0.296 & 0.000 & 0.991 \\
\hline Profitability & 24149 & 0.043 & 0.100 & 0.043 & -4.845 & 7.969 \\
\hline Payout & 24149 & 0.019 & 0.026 & 0.013 & 0.000 & 0.852 \\
\hline Equity issuances & 24149 & 0.023 & 0.083 & 0.000 & 0.000 & 4.776 \\
\hline Income taxes & 24149 & 0.010 & 0.014 & 0.008 & -0.144 & 0.365 \\
\hline Non-debt tax shield & 24149 & 0.003 & 0.021 & 0.000 & 0.000 & 2.666 \\
\hline Cash holdings & 24149 & 0.109 & 0.097 & 0.085 & 0.000 & 0.869 \\
\hline Business risk & 23499 & 2.653 & 2.129 & 2.180 & -1.060 & 12.600 \\
\hline Cash flow & 24149 & 0.030 & 0.108 & 0.033 & -4.963 & 6.805 \\
\hline Growth opportunities & 24149 & 1.206 & 1.185 & 0.870 & 0.024 & 45.813 \\
\hline
\end{tabular}

Note: the table shows the number of firm-year observations $(N)$, the mean, the standard deviation (SD),

\section{Финансовые ограничения или финансовая гибкость: что определяет выцор нулевого долга на развивающихся рынках капитала?}

\section{Д.В. Ильясов}

Выпускник программы магистратуры, научный сотрудник, Национальный исследовательский университет «Высшая школа экономики», Москва, Россия E-mail: Den.iliasov@gmail.com

\section{М.С. Кокорева}

Доцент, Национальный исследовательский университет «Высшая школа экономики», Москва, Россия

E-mail: mskokoreva@gmail.com 
Table A1 (continued)

\begin{tabular}{c|c|c|c|c|c}
\hline $\mathbf{7}$ & $\mathbf{8}$ & $\mathbf{9}$ & $\mathbf{1 0}$ & $\mathbf{1 1}$ & $\mathbf{1 2}$ \\
\hline 84.86 & 3 - Low LRPI & 316 & $0.21 \%$ & $4.24 \%$ & $9.10 \%$ \\
\hline 31.72 & 3 - Low LRPI & 176 & $2.93 \%$ & $10.66 \%$ & $6.35 \%$ \\
\hline 23.64 & 7 - High LRPI & 249 & $0.00 \%$ & $2.82 \%$ & $15.85 \%$ \\
\hline
\end{tabular}

term debt in the total amount of debt less $5 \%$ as long-term zero-debt firms (LTZD).

Table A2

STATISTICS

\begin{tabular}{c|c|c|c|c|c|c|c}
\hline \multicolumn{4}{c|}{ Financially Constrained Firms } & \multicolumn{3}{c}{ Financially Flexible Firms } \\
\hline$N$ & Mean & SD & Median & $N$ & Mean & SD & Median \\
\hline 9639 & 0.234 & 0.309 & 0.204 & 4520 & 0.245 & 0.237 & 0.216 \\
\hline 9639 & 4.270 & 1.067 & 4.311 & 4520 & 5.377 & 2.071 & 4.736 \\
\hline 9639 & 6.319 & 4.995 & 5.000 & 4520 & 9.036 & 6.040 & 8.000 \\
\hline 9639 & 1.481 & 1.354 & 1.104 & 4520 & 1.634 & 1.419 & 1.229 \\
\hline 9639 & 0.319 & 0.208 & 0.299 & 4520 & 0.306 & 0.164 & 0.298 \\
\hline 9639 & 0.038 & 0.139 & 0.045 & 4520 & 0.035 & 0.084 & 0.041 \\
\hline 9639 & 0.016 & 0.027 & 0.006 & 4520 & 0.021 & 0.024 & 0.016 \\
\hline 9639 & 0.036 & 0.108 & 0.000 & 4520 & 0.033 & 0.094 & 0.000 \\
\hline 9639 & 0.010 & 0.015 & 0.007 & 4520 & 0.010 & 0.013 & 0.008 \\
\hline 9639 & 0.003 & 0.031 & 0.000 & 4520 & 0.001 & 0.008 & 0.000 \\
\hline 9639 & 0.106 & 0.108 & 0.073 & 4520 & 0.156 & 0.114 & 0.130 \\
\hline 9372 & 2.864 & 2.360 & 2.340 & 4502 & 3.113 & 2.484 & 2.490 \\
\hline 9639 & 0.021 & 0.151 & 0.033 & 4520 & 0.024 & 0.088 & 0.034 \\
\hline 9639 & 1.222 & 1.396 & 0.837 & 4520 & 1.394 & 1.447 & 0.966 \\
\hline
\end{tabular}

the median as well as the minimum (Min) and maximum (Max) value of each variable (only for the all firms).

Данное исследование сфокусировано на пробелах в теории формирования структуры капитала, касающихся мотивов выбора нулевого уровня долга. На выборке компаний из 21 страны с развивающимися рынками капитала за период с 2010 по 2015 г. мы проследили, что выбор политики структуры капитала обусловлен в первую очередь мотивом финансовой гибкости. Вторым по значимости мотивом являются финансовые ограничения. Мы определили, что основными детерминантами выбора нулевого долга являются возможности роста, бизнес-риск, доходность компании и наличие у компании денежных средств. Наши результаты показали, что компании с нулевым долгом зачастую малого размера, менее прибыльные, более рисковые и располагают высокими денежными ресурсами. Нами установлено, что внутрикорпоративные факторы более значимы при выборе нулевого долга, чем макроэкономические условия. 
Ключевые слова: финансовые ограничения, финансовая гибкость, нулевой долг, структура капитала.

JEL: G32.

For citation: Iliasov D. V., Kokoreva M. S. 2018. Financial constraints versus financial flexibility: What drives zero-debt puzzle in emerging markets? Russian Management Journal 16 (3): 407-434. https://doi.org/10.21638/spbu18.2018.305

https://doi.org/10.21638/spbu18.2018.305

Статья поступила в редакиию 18 декабря 2017 г. Принята к публикации 26 сентября 2018 г. 